Portland State University

PDXScholar

10-30-1995

\title{
Russian-speaking Pentecostal Refugees and Adult ESL Programs: Barriers to Participation
}

Elena Valerijevna Zaitseva

Portland State University

Follow this and additional works at: https://pdxscholar.library.pdx.edu/open_access_etds

Part of the Bilingual, Multilingual, and Multicultural Education Commons Let us know how access to this document benefits you.

\section{Recommended Citation}

Zaitseva, Elena Valerijevna, "Russian-speaking Pentecostal Refugees and Adult ESL Programs: Barriers to Participation" (1995). Dissertations and Theses. Paper 4947.

https://doi.org/10.15760/etd.6823

This Thesis is brought to you for free and open access. It has been accepted for inclusion in Dissertations and Theses by an authorized administrator of PDXScholar. Please contact us if we can make this document more accessible: pdxscholar@pdx.edu. 


\section{THESIS APPROVAL}

The abstract and thesis of Elena Valerijevna Zaitseva for the Master of Arts in Teaching English to Speakers of Other Ianguages were presented October 30,1995, and accepted by the thesis committee and the department.

COMMITTEE APPROVALS :
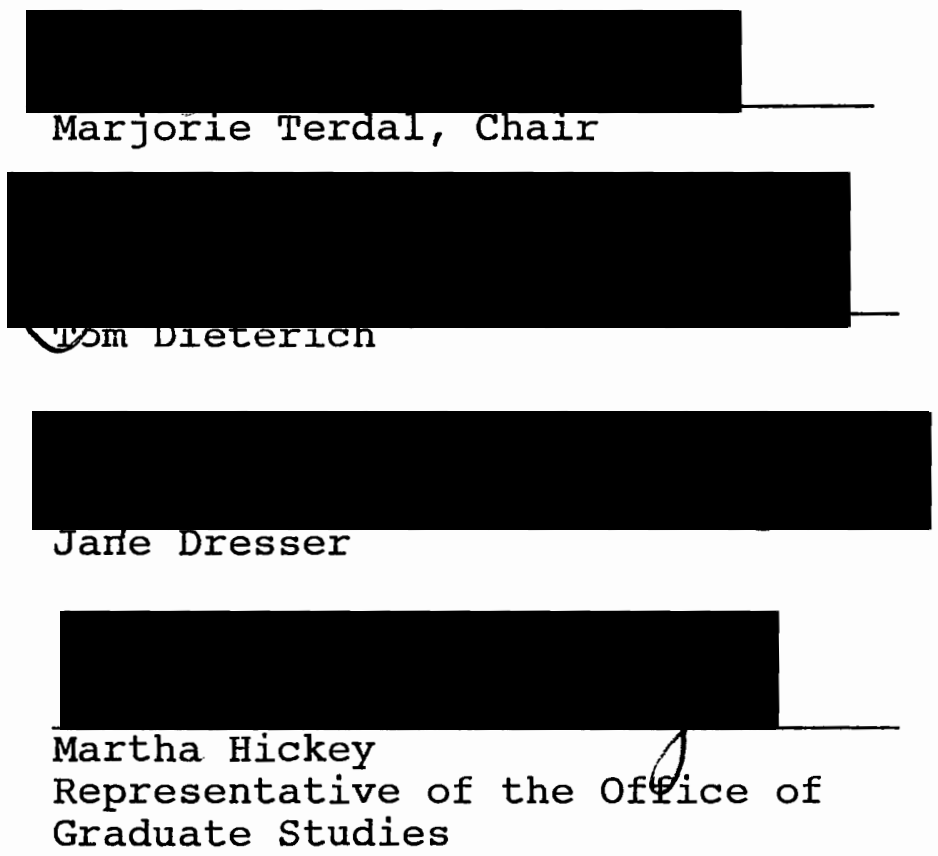

DEPARTMENT APPROVED:

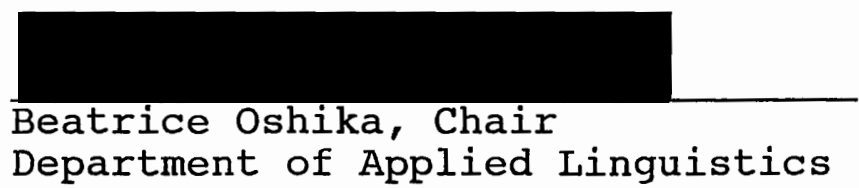

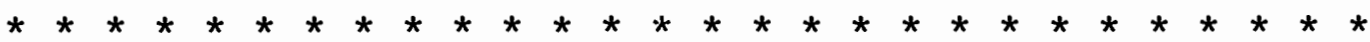

ACCEPTED FOR PORTLAND STATE UNIVERSITY BY THE LIBRARY by

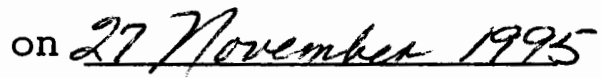




\section{ABSTRACT}

An abstract of the thesis of Elena Valerijevna Zaitseva for the Master of Arts in Teaching English to Speakers of Other Languages presented October 30, 1995.

Title: Russian-Speaking Pentecostal Refugees and Adult ESL Programs: Barriers to Participation.

Pentecostals from the former Soviet Union are the most recent and fastest growing refugee group in Oregon. Because the refugee population's low English skills may increase their dependence upon welfare assistance, their nonparticipation in ESL programs is treated as a social issue.

Efforts to increase the English literacy levels of Russian-speaking Pentecostal refugees are limited by lack of empirical data regarding forces that affect this population's decision to participate or not to participate in educational activities. The purpose of this study was to gather information about barriers to participation in ESI programs by adult Russian-speaking Pentecostal refugees. To this end the present research sought to determine (1) the importance of individual reasons for nonparticipation; (2) whether there was an underlying structure to those reasons; and (3) whether socio-demographic variables were associated with reasons for nonparticipation. 
The survey was conducted on a representative sample of 143 Russian-speaking Pentecostal adults in the Portland, Oregon area. Data were obtained with the Deterrents to Participation Scale - Form LLR (adapted from Hayes \& Darkenwald, 1988) which had two parts: socio-demographic information and 35 items which operationalized the concept "reasons for nonparticipation."

Factor analysis of the 35 items resulted in six factors: School/Self Incongruence, Low Priority of Education, Negative Attitude Towards Classes, Low SelfConfidence, Situational Barriers, and Social Disapproval.

The socio-demographic variables and factors were found to relate in logical ways. School/Self Incongruence correlated with age and number of dependent children; Low Priority of Education correlated with number of children and unemployment; Low Self-Confidence was shown to be related to age; Situational Barriers related to number of children, educational attainment and unemployment; and Social Disapproval correlated with period of attendance of ESL classes.

With the data gathered from the research, implications for practice were drawn which can be used as the basis for developing programs to meet the ESL needs of the Russian-speaking Pentecostal adults. 


\title{
RUSSIAN-SPEAKING PENTECOSTAL REFUGEES AND ADULT ESI PROGRAMS: BARRIERS TO PARTICIPATION
}

by

ELENA VALERIJEVNA ZAITSEVA

A thesis submitted in partial fulfillment of the requirements for the degree of

\author{
MASTER OF ARTS \\ in
}

TEACHING ENGLISH TO SPEAKERS OF OTHER LANGUAGES

Portland State University

1995 


\section{ACKNOWLEDGEMENTS}

I would like to take this opportunity to thank the faculty of the English Department of the Institute of Foreign Languages in Moscow, Russia for sharing their wealth of knowledge with me. I deeply appreciate the training $I$ received in that program. It directly contributed to my successful graduate studies in the United States.

Special thanks go to Dr. Marjorie Terdal, my advisor and committee chair for the time she spent guiding me in my studies and research and for revising and proofreading my thesis.

I would also like to thank Dr. Martha Hickey, Dr. Tom Dieterich, and Jane Dresser for serving on my committee and for their constructive comments and suggestions.

Finally, and most importantly, I owe the greatest thanks to my dear parents, Nina and Valery Zaitsev, who have believed in me from the start, listened to my ideas, and pushed me to follow up on them. Their unfailing emotional support and encouragement have brought me to where I am today. 
I would also like to express my heartfelt thanks to Miriam and Wade Bettis, my "American parents," who have offered their love and unconditional support throughout my stay in this country.

Thank you all very much! 
TABLE OF CONTENTS

PAGE

ACKNOWLEDGEMENTS......................... v

LIST OF TABLES....................... ix

LIST OF FIGURES....................... ix

CHAPTER

I INTRODUCTION................... 1

The Purpose................... 1

The Problem.................. 2

II REVIEW OF THE LITERATURE............ 7

Introduction............... 7

Soviet Pentecostals.............8

Deterrents to Participation in

Adult Education............... 23

III METHODOLOGY.................. 33

Introduction....................... 33

Sampling and Data Collection...... 33

Description of Respondents........ 36

Instrumentation..............4 40

Data Analysis Procedures......... 45

IV $\quad$ RESULTS......................4 49

Rank Order of Deterrents......... 49

Factor solution................. 55 
Relation of Factors to

Socio-Demographic Variables.......67 67

V

DISCUSSION.................... 74

Introduction................ 74

Rank Order of Deterrents........ 76

Factor Solution............... 77

Relation of Factors to

Socio-Demographic Variables...... 86

VI IMPLICATIONS OF THE STUDY......... 89

Implications for Research.......89

Implications for Practice....... 92

REFERENCES............................. 101

APPENDICES

A DETERRENTS TO PARTICIPATION SCALE - FORM LL...106

B DETERRENTS TO PARTICIPATION SCALE - FORM LLR..108 


\section{IIST OF TABLES}

TABLE

PAGE

I Rank Ordering of Deterrents............. 50

II Factor I: School/SeIf Incongruence......... 57

III Factor II: Low Priority of Education........60

IV Factor III: Negative Attitude Towards Classes. 61

V Factor IV: Low Self-Confidence............ 63

VI Factor V: Situational Barriers........... 65

VII Factor VI: Social Disapproval............66

VIII Correlations Between Factor Scores and

Continuous Variables..................668

IX Relationships Between Factor Scores and

Categorical variables.................69

\section{LIST OF FIGURES}

FIGURE

PAGE 


\section{CHAPTER I}

\section{INTRODUCTION}

\section{THE PURPOSE}

The overall purpose of this study was to build on earlier research (Scanlan \& Darkenwald, 1984; Darkenwald \& Valentine, 1985; Hayes \& Darkenwald, 1988) which initiated the empirical investigation of deterrents to participation in adult educational programs and to extend this line of enquiry to the previously unexamined target population - Russian-speaking Pentecostal refugees. A deterrent or barrier to participation is defined as a reason or group of reasons contributing to an adult's decision not to engage in learning activities.

The study focuses on the phenomenon of nonparticipation of the target population in English as a Second Language (ESI) programs by addressing the following objectives:

(1) assessing the importance of individual deterrents to participation for adult Russian-speaking Pentecostal refugees; 
(2) determining if individual deterrents are interrelated in such a way that meaningful source variables, or factors, can be identified;

(3) ascertaining the relationships, if any, between the identified factors and socio-demographic variables (such as age and sex).

The accomplishment of these objectives is intended to provide valuable information for the development of ESL programs that will attract more Russian-speaking Pentecostal refugees. This study may also prove useful for educators and researchers interested in better understanding of the nature of educational participation by this, yet scantily studied, ethnic minority.

\section{THE PROBLEM}

The subjects of the present study are Pentecostal refugees from the former Soviet Union. A refugee, according to the United States Federal Law (The Refugee Act of 1980), is any person who has been persecuted or has "a well-founded fear of persecution" because of his or her race, nationality, religion, political opinion or membership in a specific group. Pentecostals have been granted refugee status because in the former Soviet Union they were subject to persecution. 
Russian-speaking Pentecostal refugees from the former Soviet Union represent a significant student population for adult ESI programs, as they currently make up the largest arrival group in Oregon reaching $46 \%$ of all refugee arrivals in 1993, the last year for which complete figures are available (Refugee Report, 1993). The U.S. Department of State requires that state resettlement agencies ensure that refugees have food, housing and medical care once they arrive, and that they become self-sufficient by the end of the eight-month period of cash assistance. This necessarily triggers the ingenuity of both service providers and refugees in trying to procure jobs as soon as possible. In fact, due to shrinking federal assistance, all projects undertaken by refugee resettlement agencies are geared towards early employment. This is where development of English-language skills becomes crucial: English proficient applicants are much more likely to secure better paying jobs within shorter periods of time. Thus, nonparticipation in ESL programs by refugees not only retards their personal educational progress, it also hinders their economic advancement and, thus, increases their dependence upon welfare assistance. It is clear then, that, since the problem of nonparticipation in ESI programs by refugees is of much consequence to the society as a whole that 
carries the burden of supporting them, this concern takes on dimensions of a social issue.

Despite the increasing social relevance of inquiry into the question of participation in ESL programs by linguistic minorities in this country, very little research has been done in this area. As a rule, ethnic minorities are not included in the growing body of empirical research that focuses specifically on deterrents to participation. Much of the research completed to date by North American researchers in this field and the generalizations and inferences drawn from the results have been based on investigations of white middle-class subjects. Obviously, the findings of this research are restricted in generalizability because of failure to include adults who are diverse in ethnicity. In this context, and underlying the approach taken in the study, are four basic assumptions:

(1) Russian-speaking Pentecostal refugees represent one of the largest refugee communities in the Portland area, one which is not likely to diminish in the near future;

(2) their low rates of participation in ESL programs are problematic to society as a whole;

(3) certain factors or deterrents contribute to the problem of nonparticipation; 
(4) only by identifying and addressing these factors can providers fulfil their social role of helping this population become fully functional, productive and contributing members in American society.

Based on these assumptions, the present research focused on the phenomenon of nonparticipation in ESL programs by adult Russian-speaking Pentecostal refugees by addressing the following questions:

1. What individual reasons for nonparticipation are perceived by this population as the most important? 2. Is there an underlying structure to the reasons why eligible members of the target population choose not to attend ESL classes?

3. What socio-demographic and background variables are associated with the reasons why they do not attend ESL programs?

Data were obtained with the Deterrents to Participation Scale - Form LLR (adapted from Hayes \& Darkenwald, 1988) which is divided into two parts: sociodemographic and background information and 35 items which operationalize the concept "reasons for nonparticipation."

The survey instrument was completed by a representative sample of 143 limited English proficiency 
adult Russian-speaking Pentecostal refugees who were not at the time of the survey attending ESL programs.

The data gathered during the survey, which was conducted during a church service in one of Portland's Russian Pentecostal churches, was subjected to several statistical methods of analysis. To answer the first research question, the means of each of the 35 items on the instrument were computed and used to rank the deterrents according to their relative degree of influence. The responses to the 35 items on the instrument were then factor analyzed to answer the second research question - the identification of empirically based categories of deterrents. Finally, factor scores were used in correlational analyses with demographic and background characteristics of the sample, thereby addressing the third research question. With the data gathered from the research, implications for practice were drawn which can be used as a basis for developing ESI programs which will attract more Russian-speaking Pentecostal adults. 


\section{CHAPTER II}

\section{REVIEW OF THE LITERATURE}

\section{INTRODUCTION}

Despite rapidly growing numbers of Soviet Pentecostal refugees in the Portland area, the general public is largely unaware of the very specific character of this particular segment of population. The purpose of the first part of this chapter is to bring to the reader's attention the distinctive nature of Russianspeaking Pentecostal refugees and to provide the context for further and more fruitful discussion of the research findings.

In the first section of the chapter, the theology of Pentecostalism, the system of practices and beliefs are discussed. Section two describes the development of the Pentecostal movement in the former Soviet Union, its relationship with the Soviet state and persecution of Pentecostal believers. And, concluding the first part of the literature review, is the profile of the Soviet Pentecostal Refugees in the Portland area. 
The second part of the chapter - Deterrents to Participation in Adult Education - is devoted to the review of the germane studies of barriers to participation of adults in educational activities.

\section{SOVIET PENTECOSTALS}

\section{Beliefs and Practices}

As a religious denomination, Pentecostals (or Pentecostalists, as they are sometimes called) are the early 20th century descendants of Radical Reformation. However, because in the former Soviet Union these first evangelization contacts have since lost any immediate relationship to the present day Pentecostals in that country, the Pentecostal Church there, according to Durasoff (1989), may be considered to be a true indigenous one.

Pentecostals are extremely zealous in their worship and evangelization. The first thing that strikes one on acquaintance with the life of Pentecostal communities is the number and length of their prayer meetings. In one of the Portland Russian Pentecostal churches, for example, meetings are held daily or at least three times a week. In many congregations meetings are held twice a day: before and after work. Meetings last from two to four 
hours. On Sundays and holidays Pentecostal meetings are held two to three times during the day, the total length reaching eight to twelve hours.

As its name implies, the denomination focuses its attention on the Spirit of Pentecost, the Holy Ghost. The center point of Pentecostal theology is the coming of the Holy Spirit that manifests itself in "speaking in tongues" - an excited speech understandable only to God. Goodman (1972) describes that when "speaking in tongues" occurs, the members begin to produce unintelligible, lexically noncommunicative utterances while demonstrating an impressive concomitant kinetic behavior such as lifting arms, shaking head, twitching in the face, weeping in addition to lacrimation, salivation and perspiration, and violent shaking of the whole body. Because of such unusual behavior people in the former Soviet Union called them "Triasuni" ("shakers" or "twisters" in English). This term in Russian has a negative connotation which reflects the Western culture's psychiatric bias: inability to control behavior manifests some kind of mental derangement (Kolarz, 1962). Not surprisingly, Communist critics of religion found it easy to ridicule the Pentecostal movement by focusing attention on their eccentricities while completely ignoring the religious aspect of the movement. 
Pentecostals consider themselves living in the "end times" and believe strongly in the imminent return of Jesus Christ. Pentecostals' teachings downgrade deprivation on Earth and by concentrating on communion with the Holy Spirit and the rewards of Heaven, which are vouchsafed the faithful, help reconcile their members to a lowly social and economic status (Goodman, 1972). It is not surprising then that Pentecostals, as observed by Kolarz (1962), make converts almost entirely from among poorer members of the community and mostly in the rural areas.

The Pentecostal community cuts across ethnic and traditional national lines (Juergensensmeyer, 1993). The motivating factors are religious and are not rooted in the ethnosocial past of Russia. The result is a nonnational organization that is not potentially linked to ethnic manifestations. Although the majority of members are of Ukrainian and Russian origins, Pentecostalism made converts among people of different nationalities and national minorities in the former Asian republics of Kazakhstan, Kirgizia, Uzbekistan, as well as in Moldavia, Lithuania and Byelorussia (Bourdeaux, 1973; Hill, 1989; Kolarz, 1962). 
History of Pentecostal Movement in the Former soviet

\section{Union}

Communism views religion as a threat to its organizational and ideological monopoly. Since religious institutions offer an alternative focus of loyalty, they are either transformed and absorbed by the party apparatus, or simply eliminated (Hill, 1989; Wetter, 1969).

Along with Adventists, Jehovah's Witnesses and a few other small religious communities, Pentecostals were banned and openly persecuted in the former Soviet Union. No resolutions or enactments outlawing whole denominations were ever published by the Soviet government. Yet those denominations were de facto illegal, which was routinely admitted by the official Soviet press without reference to any documents (Bourdeaux, 1973).

The Pentecostal movement emerged, almost simultaneously, in the United States, Britain, South Africa and Scandinavia in 1906-07. Pentecostal missionaries went from these countries to many parts of the world. In America, the two Pentecostal organizations most zealous in missionary work were "Assemblies of God" and the "Church of God." In 1911 a missionary of the "Church of God" came to Helsinki, Finland, then part of 
the tsarist Empire and made the first Russian converts to the Pentecostal movement (Kolarz, 1962). The movement, however, began to spread widely in Russia only after the Communists came to power in 1917 .

The history of the relations between the Pentecostals and the Soviet state can be divided into four periods:

1) 1922 - 1928 Religious liberty

2) 1929 - 1941 Active persecution

3) 1942 - 1958 Neglect

4) 1958 - 1990 Antireligious campaign

The first period started immediately after the Revolution. The Communist Party's position against religion was clearly stated in the series of enactments of 1917-1918: all ecclesiastical property was confiscated, separation of church and school was ordered, civil marriage was introduced, all subsidies by the state were stopped, and, most importantly, absolute equality of all religious communities was proclaimed.

The edicts were directed primarily at undermining the authority of the historically powerful Russian Orthodox Church, while small Protestant sects like Pentecostals, made up primarily of useful workers and peasants, were seen by the Communist party as a counterforce, potentially useful in its struggle with the 
prior state church (Hill, 1989; Simon, 1974; Wetter, 1969). As a consequence, despite the antireligious legislature of 1917-1918, in practical reality the Pentecostal community entered a period of considerable religious liberty.

In 1922, the Soviet authorities allowed a missionary of the American "Church of God," Ivan Efimovich Voronaev, to enter the Ukrainian port city of Odessa. A Baptist preacher of Russian-Ukrainian origin, he fled tsarist persecution in 1911. As a messenger, Voronaev had considerable success: by 1926 , over the period of just four years of his preaching, 350 congregations with a total membership of 17,000 were in the Ukraine (Hill, 1989; Kolarz, 1962).

This relatively happy state of affairs under the atheist rulers lasted for seven years (1922-1929). In 1929 the infamous "Law on Religious Association" codified all earlier antireligious laws and also granted freedom of antireligious propaganda. The stipulations concerning the separation of church and school were interpreted to mean that religious instruction of young people under eighteen years of age was forbidden. Private instruction was permitted if not more than three people assembled. Thus, "freedom to exercise a religious cult" meant clearly that the church was merely permitted to hold 
services in an officially registered building. Any proclamation of the Word outside of the church building (such as mission work, evangelism, unofficial printing and distributing of religious literature and cultural contribution to the community) was forbidden (Bociurkiw, 1969; Simon, 1974 ) .

Without any kind of organizational structure (according to Blane (1977), this church in the former Soviet Union has no rigid single organization and is under no external hierarchy) the Pentecostal Church survived through this persecution period: small Pentecostal circles were able to go underground and assemble in secret and, thus, remained unabsolved by the state and the party (Kolarz, 1962).

The Soviet Union's involvement in the Second World War brought a third period (1942-1957). The Soviet state, threatened by a powerful enemy, was forced to moderate the attack on religion. In new circumstances it could not afford the alienation of any of its citizenry and sought help from the church which could assist in exerting moral leadership. Atheist publications were stopped, successful patriotic appeals were made in the churches. Although Soviet Protestants in general rallied to the defense of the nation, there is no evidence that Pentecostals supported the Soviet war effort (Hill, 1989) • 
After the War the Soviet regime forced Pentecostals to amalgamate with the Baptists and Evangelical Christians by creating the Council of Evangelical Christians and Baptists: the totalitarian regime desired to have one large, easily supervised sectarian organization. This institutionalization created a pattern of close state supervision and stiffening prosecution of unregistered churches (Bourdeaux \& Reddaway, 1969; Kolarz, 1962; Durasoff, 1990).

The Evangelical-Baptist-Pentecostal union, however, did not prove to be a working proposition (Kolarz, 1962; Simon, 1974). Considerable theological differences as well as "peculiar" behavior during services set off the Pentecostal congregation from the community at large and from both the Catholic and the other Protestant groups. As a consequence, many Pentecostals wished to remain outside the united official body and continued their activities underground in hope of forming an independent Pentecostal Church.

Toward the end of the 1950s the alliance between church and state that evolved during the war came to an end. Under the banner of de-Stalinization, Khrushchev launched a massive attack on all organized religion (Bociurkiw, 1969). It was continued by Brezhnev and persisted untill 1988, when Gorbachev came to power. 
In its most virulent stage this antireligious campaign lasted from 1958 to 1964 (Durasoff, 1989; Hill, 1989). At this time the state issued new instructions for strict implementation of the "Law on Religious Associations" of 1929; rules of assembly, youth policy, printed matter, education and family policies were stiffened; state policy focused more strongly on its registration policy, wherein it was illegal not to register but virtually impossible to do so; an aggressive antireligious propaganda campaign was launched.

Interestingly, Pentecostalism became an important religious movement in the Soviet Union during this particularly oppressive period. Originally confined to the Ukraine and Byelorussia, Pentecostalism spread to European Russia and many parts of Asia, especially Kirgizia, Kazakhstan and Uzbekistan.

Several factors account for the proliferation of Pentecostalism. One of them, according to Juergensensmeyer (1993), is its international nature: the Pentecostal church addresses itself equally to all ethnic groups. Another one, according to Kolarz (1962), is the deliberate migration of entire Pentecostal groups, which is prompted by the desire to avoid persecution, to go to new areas where they are unknown and also by the 
apocalyptic search for a legendary country where evil does not rule.

Membership in the Pentecostal movement often implies a negative attitude toward the state authorities (Kolarz, 1962; Hecker, 1993). The Soviet Pentecostals often defy strict legislation about religious activities and challenge certain civil obligations (for example, military training and service in the army).

A number of trials were held in the 1960s on account of the Pentecostals' "anti-social" attitudes, such as alienation of young people from Soviet life, refusal to serve in the Army and hostility to soviet education (in the former Soviet Union every school child of twelve was taught evolutionary science, which opposes the doctrines of the Pentecostal theology). Bourdeaux (1973), Hill (1989), and Simon (1974) report that Pentecostals were often accused of indulging in dangerous religious fanaticism: the religious rites of the church the holy salutation, the washing of the feet, the breaking of bread, "speaking in tongues" with God - were described as harmful to health and the human psyche and were cited in connection with the spread of infectious diseases. Occasionally accusations were even more serious, going as far as to say that Pentecostals were guilty of immoral practices and child-sacrifice. Such 
accusations are part of the antireligious hysteria waged by the Soviet state when it felt threatened by the spread of the Protestant movement.

The measures that the Soviet government took against the sectarians were extremely harsh (Bourdeaux, 1973; Hill, 1989; Kolarz, 1962). Very often Pentecostal leaders were put in mental institutions, or sentenced to three to six years in jails or strict-regime camps, their property was confiscated, and children were removed from parents. The great revival of religion in the $1980^{\prime}$ s came as a result of Gorbachev's policies of glasnost and openness. Soon after he came to power in 1985, he adopted a gentle policy toward religious organizations and in 1987 called for a release of religious prisoners. Pentecostals were allowed to emigrate the same year (Hiller, 1989).

In conclusion, it is important to note that despite the spread of Pentecostalism, this religious community had never been thriving and never gained ground under the Soviet rule.

\section{Soviet Pentecostals in the Portland Area}

Oregon seems to be a very popular destination for refugees from about a dozen countries in the former Soviet Union, Southeast Asia, eastern Europe, Africa and 
the Caribbean. According to the Refugee Report (1993, p.20) the state ranks 11 th nationally in total number of resettled refugees, even though it is 29 th in population. It ranks even higher - fourth - in refugee concentration (1.107\% of the general population).

Due to internal political changes in the former Soviet Union, starting with 1988, Soviet Pentecostals started to emigrate in large numbers to the United States. They are being resettled in ten major sites around the country, Oregon being one of them. This state initially attracted Pentecostals because of the Russianspeaking community in the Woodburn area, which also included one long-standing Pentecostal congregation in Hubbard.

The Refugee Report (1993, p.38) also provides a detail of the total numbers of refugees arriving in Oregon since 1975. It indicates that from 1975 to 1987 the Southeast Asians were by far the dominant refugee group. Since 1988, however, there has been a significant shift in the countries of origin: internal political changes in the Soviet Union relaxed restrictions to emigrate, allowing large numbers of people to leave. As a consequence, after 1988 the refugees coming to Oregon have primarily been non-Asians. The overwhelming majority of the non-Asian refugees in Oregon are former Soviets. 
Their numbers increased drastically from none before 1988 to $14 \%$ of annual refugee arrivals in $1988,65 \%$ in 1989, then slowly declined to 57\% in 1990 and 1991, 54\% in 1992 and $46 \%$ in 1993, the last year for which the numbers are available. According to the Report, almost all soviet arrivals are Pentecostals. Although the peak of Pentecostal immigration to Oregon has apparently passed, Oregon will probably continue to resettle some refugees who already have families in the state (U.S. refugee guidelines allow for families to be reunited) as well as what is called "second-stage" relocation from other states.

The State Refugee Program does not keep track of refugee relocations from or to other states after the resettlement. Thus, it is virtually impossible to give exact numbers of Soviet Pentecostal refugees residing in the Portland area (the counties of Multnomah, Washington and Clackamas) at a certain time. Provided that, upon their arrival from the former Soviet Union to Oregon, the Soviet refugees have not moved, there must be about 7,000 of them in this state, with the majority residing in the Portland area.

Several agencies and programs are involved in resettlement of refugees. The Refugee Early Employment Program provides four to six weeks of English classes and 
instruction in skills like resume-writing and interviewing. Government support covers housing, food and medical care for the first eight months of resettlement. After that, refugees are expected to become selfsufficient. The majority of Soviet Pentecostal Refugees apply their blue-collar backgrounds to find work in ship yards or factories where low wages are the norm. In 1993 the average wage for Soviet refugees was $\$ 5.66$ (Refugee Report, 1993, p.74).

According to the Refugee Report (1993), one of the main characteristics of Soviet Pentecostal refugees is that as a group they contain a large number of older persons, members of extended families. These are people with chronic but not debilitating medical problems, who had already reached retirement (55 for males and 50 for females) in the Soviet Union. They resist entering the labor market, citing old age or medical problems. Also, many Pentecostals regard birth control as sinful. As a result, their families are large; the age of children sometimes spreads over two decades. Restricted by such large families, Pentecostal women do not work outside the home. All that creates financial pressure, as well as pressure on the family. According to Dr. Dina Birman, who works in the Refugee Mental Health Branch of the U.S. Public Health Service, Pentecostal Refugees experience 
very high stress levels that play out in domestic violence and mental-health problems (Oregonian, June 26, $1994)$.

The significant resettlement problems experienced by Pentecostal refugees primarily stem from major cultural differences. Upon their arrival in the United States, people from the communist countries, where incentives for individual endeavor have been absent, have certain expectations from the government. Those expectations include free medical coverage, a choice of jobs, a wage sufficient to support their big families, "governmental" pensions for the retired, and free housing. Due to huge discrepancies between the expectations and the realities of Iife in the United States, the process of acculturation for this population is particularly painful and very often results in high levels of emotional strain.

Perhaps the greatest challenge for Soviet Pentecostals is communication. The language barrier not only cuts them off from the dominant culture and makes them totally dependent on their children, but also considerably limits their employment opportunities. Driven by the necessity to make refugees self-sufficient and fully functioning members of the society, the Refugee Early Employment Program in cooperation with Portland 
Community College operates English-as-a-Second-Language classes that are open to any refugee interested in learning English. The ESL curriculum is based on survival skills. The program is free of charge and offers six levels of ESL classes. The classes are held three times a week for three hours each day. At the end of each term the students are assessed by the teacher and, if qualified, are passed on to the next level. Why many adults choose not to attend these classes is the main research question of the present study. The literature concerned with the deterrents to participation in adult education is reviewed in the next part of the chapter.

\section{DETERRENTS TO PARTICIPATION IN ADULT EDUCATION}

In North America researchers have focused on a variety of factors that might affect an individual's decision to engage in educational activities. Most of these factors can be categorized as (1) reasons for participation and (2) deterrents to participation. Thus, two main orientations for research on participation in educational activities are recognized by the academic community: one that focuses on the study of motivation; and the other, characterized by an interest in deterrents to enrollment. This section offers an overview of some of 
the literature concerned with explaining forces that hinder the participation of adults in organized educational activities.

Theory based research on participation, especially early research, concentrated on identification of learner types and on motivations (Boshier, 1971; Boshier \& Collins, 1985; Burgess, 1971; Sheffield, 1964). The emphasis in these studies was on what causes learners to participate, not what deters them. However, even early research contained deterrents as an important construct. Johnstone and Rivera (1965) were the first to address the issue of deterrents. As part of their four-phase national study of the nature and magnitude of American adults' participation in continuing education, the researchers deductively generated a list of ten discrete reasons for nonparticipation and asked their subjects (who were solely non-participants) to indicate whether or not each reason applied to them. Not only did the researchers ascertain the relative significance of the ten barriers, they also investigated the relationships between the frequency with which the various deterrents were reported and selected demographic characteristics of the sample. The findings confirmed many heretofore speculative assumptions and deterrent perceptions (for example, the finding that older adults and those occupying lower 
socio-economic strata of society were disproportionately represented among nonparticipants in adult education; strength of cost and time as the most influential deterrent)

In another national study conducted by the Commission on Non-Traditional Study (Carp, Peterson \& Roelfs, 1974) Johnstone and Rivera's list of deterrents was enlarged from ten to 24 , thus providing for a more detailed portrayal of various elements that impinge upon adults' participation in educational activities. The findings of this research confirmed and substantiated those of Johnstone and Rivera (1965).

These early surveys, however, shared some weaknesses. Cross (1981) in her review and critique of the early findings pointed out such limitations as (1) deductive generation of deterrents by researchers themselves which, consequently, made the deterrents particularly prone to social bias and (2) unsophisticated design of the surveys that limited treatment of the data to the simplest types of statistical analysis.

Despite the weaknesses of the early research, it was significant in that it included deterrents to participation as a pertinent variable.

In their study Johnstone and Rivera (1965) also provided the first insight into a potential structure of 
deterrent construct. They intuitively divided the ten discrete deterrents into two broad categories: (1) situational, which are external to the individual's control; and (2) dispositional, which are based on personal attitude.

Subsequent replications of Carp, Peterson and Roelfs's study provided evidence in support of the reliability of the findings. Cross (1981) analyzed data from about 30 such studies and developed a descriptive typology of barriers to adults' participation in educational activities. To situational and dispositional barriers devised by Johnstone and Rivera she added the category of institutional barriers, which refer to all things about the educational institution that discourage participation, such as class times and location.

Elaborating upon Cross's deterrent classification framework, Darkenwald and Merriam (1982) added one more category of barriers to participation - informational, which along with the institution's failure to communicate information about programs, also includes failure of the adults to seek out and use the available information. They also connected dispositional barriers with low socioeconomic status, breaking the concept down further to include adults' negative evaluations of the usefulness 
and pleasurability of education, a fear of failure, and low self-efficacy.

Even though the construct of deterrents to participation occupied an important place in the so far reviewed studies and was central to most models of participation (Cross, 1981; Darkenwald \& Merriam, 1982; Rubenson, 1977), all these earlier studies were still focused on motivation, that is on what impels rather than deters participation. In 1984 Scanlan and Darkenwald (1984) observed, "motivational orientation factors have not proved useful in distinguishing participants from nonparticipants" (p.155) and concluded that since the construct of deterrents is central in many participation models, more studies are needed to develop an approach designed to illuminate the construct of deterrents through empirically based inquiry. They initiated this line of research with their study of deterrents to participation in continuing education for health professionals (Scanlan \& Darkenwald, 1984). Their study included the development and utilization of a Deterrents to Participation Scale. The 40-item instrument was constructed inductively both through exhaustive literature search and interviews. Of particular value were the results of factor analyses of the data, which yielded a six-factor conceptualization of deterrents, 
that is, the six major forces that hindered participation in continuing education for this population. The underlying structure of these factors was found to differ substantially from the earlier intuitive conceptualization proposed by Cross (1981). Specifically, with regard to the "situational" category of deterrents, three distinct factors emerged: Family Constraints, Cost, and Work Constraints. With respect to "institutional" deterrents, only one factor, Lack of Course Relevance, fit this category, whereas Cross had enumerated several sub-categories.

These findings clearly suggested that the deterrent frameworks intuitively constructed by Johnstone and Rivera (1965), Cross (1981), and Darkenwald and Merriam (1982) (two, three, and four components, respectively) represented early, simplified conceptions of the factors deterring adults from participating in educational activities .

The findings of this first empirically based research on deterrents were not, however, widely generalizable, since the research was done on a narrow, homogeneous population. In an effort to enhance generalizability of the findings Darkenwald and Valentine (1985) developed a generic form of the Deterrents to Participation Scale (DPS-G) to measure deterrents among 
the general adult population. In constructing the DPS-G the researchers adopted the same rigorous approach as in the previous study. In addition, the prototype scale was subjected to standard item analysis procedures, including determination of internal consistency and, finally, was pretested. The subsequent factor analysis of the returned instrument led to the following six factors: Lack of Confidence, Lack of Course Relevance, Time Constraints, Low Personal Priority, Cost, and Personal Problems.

As in the original Scanlan and Darkenwald (1984) study, the six deterrent factors provided support for the complexity of structure underlying the deterrent construct. They concluded "that an individual's decision not to participate in organized adult education is typically due to the combined or synergetic effects of multiple deterrents, rather than just one or two in isolation" (p.187).

Of particular importance was also the observation that the six well-defined and conceptually meaningful factors yielded by this study differed substantially from the original six DPS factors (Scanlan \& Darkenwald, 1984). Only one (Cost) was identical. This important finding suggested that the underlying configuration of the deterrent construct varies according to the characteristics of the group studied. 
Scanlan and Darkenwald's (1984) and Darkenwald and Valentine's (1985) rigorous approach to scale construction and administration was adopted by a number of researchers (for example, Hayes \& Darkenwald, 1988; Martindale \& Drake, 1989; Blais, Duquette \& Painchaud, 1989; Beder, 1990) who examined the nature and impact of deterrents on different subgroups (low-literate adults, Air Force personnel, female nurses, and adults eligible for adult basic education).

Hayes (1989) looked more specifically at deterrents to participation in ESI classes by Hispanic adults. She factor analyzed reasons given for nonparticipation, which had been obtained with the help of the Spanish translation of Deterrents to Participation Scale - Form Low Literate (DPS-LL) developed by Hayes and Darkenwald (1988). Findings, which were derived from a sample of 200 ESL Hispanic students, indicated that there were four basic deterrents to participation: Self/School Incongruence, Low Self-Confidence, Lack of Access to Classes, and Situational Constraints. Although Hayes's work contributed to the analytical depth of nonparticipation study, the fact that the research subjects were all participants in ESL programs constituted a limitation of the study. 
Review of empirical studies that followed Scanlan and Darkenwald's (1984) and Darkenwald and Valentine's (1985) research clearly indicates that the derived factor strictures, while reflecting the unique aspects of different groups of population, also capture some pronounced similarities among them. In his comprehensive review of the literature on deterrents, Scanlan (1986) proposes that a synthesis of the research findings suggests that there are six distinct categories of deterrents that emerge in most settings and with most populations: (1) individual, family, or home-related problems; (2) cost concerns; (3) questionable worth or relevance of educational opportunities; (4) negative perceptions of the value of education; (5) lack of motivation or indifference to learning; and (6) lack of self-confidence.

Concerning Russian-speaking Pentecostal refugees in particular, hardly any research has been conducted on this most recent refugee population. Exceptions are three recent studies from Portland State University: one, by Amy Roberts (Locke \& Roberts, 1991) dealing with the acculturation of the Soviet Pentecostal refugees, another by Patricia Wiggins (Wiggins, 1994), who looked into educational and core values of this population, and the third by Sharon Link (Link, 1995), who looked at behavior 
of Soviet Pentecostal secondary students. The present study addresses the need to increase the rate of research and publications on the ethic minority which represents a significant proportion of the general refugee population and is, thus, a group of great potential concern to educators. 


\section{CHAPTER III}

\section{METHODOLOGY}

\section{INTRODUCTION}

The purpose of the study was empirical investigation of the forces that deter adult Russian-speaking Pentecostal refugees from participating in ESL programs.

This chapter is divided into four sections. Section one discusses the data collection procedures. Section two describes the participants of the survey. Section three describes the survey instrument. Finally, section four gives an overview of statistical procedures used for data analysis.

\section{SAMPLING AND DATA COLLECTION}

The target population of the study are adult (ages 18 and older) Iimited English proficiency Russianspeaking Pentecostal refugees in the Portland area (Multnomah, Washington and Clackamas counties of Oregon). 
Because Soviet Pentecostals were severely persecuted throughout the history of their existence, they developed into very closely knit communities that tend to mistrust any government authority and treat with a great deal of caution any outsider who expresses unsolicited interest in any aspect of the community's life. Apart from the native language and "Soviet life" experiences, the researcher has very little in common with the studied population. To overcome this barrier and win the trust of the targeted population, it was decided to contact Pentecostal Ministers (they are referred to as Pastors or Preachers) - undeniably, the most respected people in the community .

The researcher contacted six out of about a dozen Pentecostal churches in the Portland area by phone. The researcher introduced herself, described the purpose of the research and explained its value for the Pentecostal community. All Pastors agreed that such research was needed but were reluctant to have it done in their particular congregations. Some admitted that they felt uncomfortable conducting research initiated by an outsider. The researcher then decided to approach a congregation in a different way. She was personally introduced to the Pastor of one of the largest Pentecostal churches in Portland by five members of the 
congregation, who were formerly her English students. The Pastor and the elders of the church reviewed the questionnaire and discussed the researcher's request to facilitate the survey.

The survey was administered on a date selected by the Pastor. After the Sunday service the Pastor introduced the researcher to the congregation of about 300 adults. The questionnaire was distributed and completed anonymously and on a voluntary basis by adults who were not at the time attending ESL programs. The researcher assisted during the survey to answer subjects' questions in Russian.

A total of 152 respondents completed the survey instrument. Nine questionnaires with missing data were eliminated from the sample, leaving a working number of 143 cases.

Due to the population's mobility and lack of a tracking system to register the numeric changes, it is impossible to cite the exact number of Pentecostal refugees in Oregon at any given time. By very approximate estimates of employers at the Refugee Early Employment Program, there might be about 4,000 Soviet Pentecostal adults residing in the Portland area. If that, in fact, is true, then the sample of 143 individuals is large enough to reach the $95 \%$ level of confidence along with a 
margin of error that does not exceed 8\% (Dowdy \& Wearden, 1983). In other words, the sample of 143 individuals was large enough so that, in general, one can be 95 percent confident that if 50 percent of the sample has a certain characteristic, the true percentage of the population having this characteristic lies between 42 and 58. The figures imply that the sample size is representative of the targeted population.

\section{DESCRIPTION OF RESPONDENTS}

Demographic information gathered along with the questionnaire data revealed that the overwhelming majority of respondents (90.2\%) were Russians, 13 individuals (or 9.1\%) were Ukrainians and one was Byelorussian.

There was an almost equal representation of males and females in the sample (47\% and 53\% respectively). The respondents had lived in the United States for periods of time ranging from less than a year to six years with three years as the average.

The age of the respondents ranged from 19 to 71 . The majority of subjects (57.8\%) were from 30 to 48 years old. The mean age of the group was 44 years. 
Half of the subjects were unemployed. Of 62 male subjects eligible for work (up to the retirement age of 65), almost one third (20 subjects) were not employed. In contrast, out of 73 women eligible to work (under the retirement age of 60), more than a half (48 individuals) were not employed. This is consistent with the fact that due to large families, Pentecostal women traditionally are not expected to work. More interesting and meaningful, however, is the fact that out of 25 women who do work, at least eleven would not, normally, be employed, since all of those eleven women had from one to four children below age 17 . This statistic is significant in that it reflects resettlement problems and cultural gaps that the Soviet Pentecostal refugees have to deal with and that were described earlier: due to a number of circumstances (limited English proficiency being one of the most important) men can not easily find jobs to support their big families, which forces the women to join the work force.

Only $24 \%$ of the respondents indicated that they had no dependent children. The ages of dependent children ranged from up to a year (47.4\% of all the children) to 17 years of age. The average age of the youngest child was five years. 
The group had completed an average of ten and a half years of schooling in the former soviet Union. This education level of respondents is expected in the population: ten years of elementary and secondary education was compulsory in the former Soviet Union. Only fifteen individuals, all between ages 50 and 71 , had not completed the compulsory education. And only four of the respondents had gone to higher educational establishments. Taking into account the system of education in the Soviet Union, one can conclude that almost all respondents (91\%) completed their education in vocational schools, which means that in the former soviet Union they were most probably blue-collar workers.

The overwhelming majority of the subjects (88.7\%) had not studied English prior to their immigration to the United States. Those who had, had completed an average of three and a half years of English instruction.

Although none of the subjects were at the time enrolled in ESL programs, their participation status revealed that 54 individuals had never participated in ESI programs while 89 at some time had. The length of their attendance of ESL programs varied from one to ten months.

Although the sample which resulted is as representative as possible given the logistical and 
budget constraints, there are two possible sources of bias that merit mention. First, since the survey was conducted immediately after a Sunday service that lasted for four hours, some families with a lot of children or small children chose not to stay to complete the questionnaire. As a result, the sample may be skewed towards subjects with fewer or older children. Second, there may be some non-response bias. However, upon conducting a direct comparison of demographics of the respondents with those of the total population (Refugee Reports 1991, 1992, 1993), it became clear that the descriptive picture of the respondents in this study is remarkably consistent with the main characteristics of the targeted population. Thus, despite possible bias, the sample does not appear to be seriously skewed.

The demographic profile of the respondents in the present study also fits major characteristics of American adult non-participants in basic and continuing education, who, compared with the participants, are described as typically older, less well educated, more likely to work in an unskilled or semiskilled occupation and who belong to lower social and economic strata of society (Anderson \& Darkenwald, 1979; Booth, 1961; Johnstone \& Rivera, 1965; Peterson \& Roelfs, 1974). 


\section{INSTRUMENTATION}

The instrument in this study - "Deterrents to Participation Scale - Form LL" (DPS-LL) - was originally developed for use with low-literate adults (Hayes \& Darkenwald, 1988). DPS-LL (see Appendix A, Deterrents to Participation Scale - Form LL) consists of 32 items, each representing a discrete deterrent to participation. The items were identified through interviews with lowliterate Adult Basic Education students, Adult Basic Education teachers, and an extensive literature review. The reliability of the DPS-LL was found to be .82 in the initial study (Hayes and Darkenwald, 1988).

The DPS-LL was translated into Spanish (DPS-LLS) for the study of barriers to participation in ESL programs of Hispanic adults (Hayes, 1989).

For the present study the DPS-LL was translated into Russian. The translation was done by the researcher, who is a native speaker of Russian and who had extensive experience in Russian-English and English-Russian translation and interpretation.

Because the original English version of the DPS-LL was already validated, the main requirement of the translation project was for the Russian translation to be as close to the original as possible. To achieve high 
standards of accuracy and completeness of the translation, it was necessary to account for the dialect and regional linguistic differences of the targeted population (the subjects came to the United States from different regions of the former Soviet Union). It was decided to use the Standard Russian variety (the language of $T V$, radio, press) of the Russian Language for the following reasons:

1) this is a variety understood by all Russian-speaking population;

$2)$ it is neutral in relationship to other dialects and varieties of the Russian language;

3) there were no qualified translators familiar with the varieties spoken by the targeted population;

4) this is the variety spoken by the researchertranslator and, thus, the one she felt most comfortable to translate the instrument into;

5) a translation was sought which would be useful to future researchers interested in using the Russian translation of this instrument. Since DPS-LL was developed specifically for lowliterate adults and, thus, utilized the most common language and syntax, characteristic of lower reading levels, the instrument was fairly easy to translate. 
In choosing vocabulary, grammatical structures and form of the translation, the researcher was guided by such unique characteristics of the subjects as age, level of education, differences in systems of education, and circumstances in which the instrument was to be administered. In general, the most common terms and simplest grammatical structures were preferred. The accuracy of the initial translation was evaluated by a native speaker of English, whose credentials include a Secondary Education certificate and a Master's Degree in Russian. This individual was selected for her familiarity with the targeted population and their culture: she has had quite extensive experience in acting as an interpreter/translator for the Russian Pentecostal community in the Portland area. Her insight into the language was very helpful and some changes (mostly simplification of the syntactical structures) were made to the initial translation.

Finally, the revised translation was pilot tested with five members of the targeted population. The purpose of the pilot study was to provide a check of intelligibility and readability of the translation. Their comments indicated that the translation was satisfactory. These individuals were also requested to suggest additional reasons that might prevent them from 
participating in ESL programs. Two reasons were identified and eventually added to the final version of the questionnaire:

1) item 34: "It is easier for me to learn English if teachers explain rules in my native language";

2) item 35: "I tried to sign up for free ESL classes but was told that I am not eligible."

The pilot study also indicated that the time needed for the completion of the instrument was about fifteen minutes, thereby making it easy to administer during a church service.

Other modifications to the DPS-LI included:

1) reason 1 in the original DPS-LL - "I couldn't pay for child care or transportation" - was split into two separate deterrents: (1) "I can not pay for transportation" and item (33) "I can not pay for child care."

2) the original DPS-LL and its Spanish translation DPSLLS were administered to subjects who at the time of the survey were participating in Adult Basic Education (Hayes \& Darkenwald, 1988) or ESL (Hayes, 1989) programs. In those studies the respondents were asked to indicate how important each reason was BEFORE they began to attend the classes. That is why both in DPSLL and DPS-LLS, the reasons for nonparticipation were 
stated in the past tense. Because the present study was planned to survey subjects, who at the time of the administration were not participating in ESL programs, the statements were changed into the present tense.

Accuracy of translation is critical for validity and reliability of any research. There is a very strong argument for the adequacy of the translation performed for the present study: the ranking of deterrents in the present study is very consistent with Cross's typology of deterrents (Cross, 1981) and very similar to the ranking of deterrents in Hayes and Darkenwald's (done with DPSLL) and in Hayes's (done with DPS-LLS) studies (see "Rank Order of Deterrents" in the methodology section for more detailed discussion). Thus, it was concluded, that on the whole the Russian translation of the DPS-LL was equivalent to the original and understood by the targeted population. The final version of the translated questionnaire with all modifications is identified in the present study as the DPS-form LLR (see Appendix B, Deterrents to Participation Scale - Form LLR) •

The DPS-LLR directions begin with introduction of the researcher and explanation of the purpose of the research. In this section of the instrument it is also 
mentioned that the questionnaire is anonymous and that its completion is voluntary.

The second section of the DPS-LLR includes eleven socio-demographic items which proved to be potent variables in previous participation studies. Variables include sex, age, native language, number of years in this country, employment, number of children and the age of the youngest one, participation in ESL programs status, level of education in the former Soviet Union.

The questionnaire itself starts with the instruction to indicate to what extent each of the 35 items comprising the instrument are influential in their decision not to participate in free of charge ESL programs. The respondents selected their responses from a 3-point Likert scale ( 3 being most important).

\section{DATA ANALYSIS PROCEDURES}

Several methods of data analysis were necessary to accomplish the three research objectives.

The first step in data analysis was to compute basic descriptive statistics to ascertain the parameters of the sample. Subsequently, the means of each of the 35 items of the DPS-LLR, which was used as the instrument of the survey, were used to rank the deterrents according to their relative 
degree of influence, thus accomplishing the first objective of the study.

To accomplish the second objective - the identification of empirically based categories of deterrents - the responses to the 35 items on the instrument were factor analyzed.

Because of uncertainty regarding the categorization of deterrents for the surveyed population, exploratory rather than confirmatory methods were used. Two different types of factor analyses - Maximum Likelihood and Principle Components employing both orthogonal or Varimax (resulting in uncorrelated factors) and oblique (resulting in correlated factors) rotations were requested. The resulting four factor solutions were carefully examined. In all cases the oblique solution at each level was substantially similar to the orthogonal solution at the same level. As was explained by the statisticion performing the factor analysis, because orthogonal solutions are more parsimoniously interpreted than oblique solutions and because the planned correlational procedures perform better on relatively uncorrelated variables (the derived factor scores), an orthogonal solution was considered appropriate in the present case. 
Several criteria were used to evaluate and select between orthogonal rotations of Maximum Likelihood and Principle Components. The eigenvalues of the factors were examined as indicators of the amount of variance explained by each dimension. The scree test was used to indicate the point at which the contribution of additional factors to an explanation of variance in the data began to level off.

Ultimately, factor solution of Principle Components with Varimax rotation was selected for the analyses. A final factor solution was selected on the basis of the interpretability of the factors and simplicity of the factor structure.

The next step in data analysis was to determine whether reasons for not participating in ESL programs were associated with demographic traits, thereby addressing the third research question. To do so, standardized factor scores were computed using the rotated pattern matrix. These factor scores were subsequently used in correlation analyses.

The socio-demographic variables employed in the analysis were scored as follows: $\operatorname{sex}($ female $=1$, male $=$ $2)$, age (number of years), employment status (employed = 1, unemployed $=2$ ), previous attendance of ESL classes (number of months). Since these variables include both 
continuous (for example, age, number of dependent children, etc.) and categorical (for example, sex and employment) variables, two types of correlational procedures were employed: Pearson's correlations for continuous variables and the Chi-square procedure for the categorical ones.

Pearson's correlations are summarized in the form of correlation coefficients in Table VIII, while Chi-square results are represented in Table IX as means scores.

Correlation coefficients were tested for significance. Only those, with probability value of less than .05 and .001 were marked as significant correlations.

The Difference of Means Test was used to test the significance of categorical factors. The same, as with continuous variables, levels of significance (less than .05 and less than .001 ) were employed to judge how significant the relationships were. 


\section{CHAPTER IV}

\section{RESULTS}

\section{RANK ORDER OF DETERRENTS}

The individual deterrent items were ranked according to mean importance ratings. Table I presents all 35 items in rank order according to item mean. It also illustrates the comparisons with the Hayes findings of deterrent rank ordering in her study of barriers to participation in ESL programs of Hispanic low-literate adults (Hayes, 1989). In that study Hayes utilized the Spanish translation of the original DPS-LI which she identified as DPS-LLS.

of particular interest is the fact that the deterrent "It is easier for me to learn English if teachers explain rules in my native language" (which was not included by Hayes in the study of Hispanic adults and which was added to the DPS-LL after consultations with representatives of the targeted population) was perceived by the respondents as the most influential barrier to their participation in ESL programs with the item mean 2.51, which is by far higher than the mean item mean 1.34 . 
TABLE I: RANK ORDERING OF DETERRENTS

\begin{tabular}{|c|c|c|c|}
\hline $\begin{array}{l}\text { DPS- } \\
\text { LIR } \\
\text { Rank }\end{array}$ & $\begin{array}{l}\text { DPS- } \\
\text { LLS } \\
\text { Rank }\end{array}$ & Variables & Mean \\
\hline 1 & * & $\begin{array}{l}\text { It is easier for me to learn English } \\
\text { if teachers explain rules in my native } \\
\text { language }\end{array}$ & 2.51 \\
\hline 2 & 2 & $\begin{array}{l}\text { I think it will take too long for me } \\
\text { to finish school }\end{array}$ & 1.80 \\
\hline 3 & 5 & I can't pay for transportation & 1.78 \\
\hline 4 & 4 & $\begin{array}{l}\text { I don't think I can go to classes } \\
\text { regularly }\end{array}$ & 1.69 \\
\hline 5 & 5 & I can't pay for child care & 1.65 \\
\hline 6 & 10 & $\begin{array}{l}\text { The classes are held at times when I } \\
\text { can't go }\end{array}$ & 1.61 \\
\hline 7 & 1 & I don't have time to go to school & 1.58 \\
\hline 8 & 15 & $\begin{array}{l}\text { I tried to start classes but they were } \\
\text { already full }\end{array}$ & 1.53 \\
\hline 9 & 22.5 & $\begin{array}{l}\text { It's hard for me to admit that I need } \\
\text { help with English }\end{array}$ & 1.44 \\
\hline 10 & 6 & $\begin{array}{l}\text { I don't have any transportation to } \\
\text { school }\end{array}$ & 1.42 \\
\hline 11 & 13 & $\begin{array}{l}\text { I am afraid I am not smart enough to } \\
\text { do the work }\end{array}$ & 1.41 \\
\hline 12 & 3 & $\begin{array}{l}\text { It's more important to get a job than } \\
\text { go to school }\end{array}$ & 1.40 \\
\hline 13 & 12 & $\begin{array}{l}\text { I don't know there is any place to go } \\
\text { to take classes }\end{array}$ & 1.38 \\
\hline 14 & 7 & $\begin{array}{l}\text { I don't know anyone who is attending } \\
\text { classes }\end{array}$ & 1.26 \\
\hline 15 & 9 & $\begin{array}{l}\text { I think starting classes will be } \\
\text { difficult with lots of questions and } \\
\text { forms to fill out }\end{array}$ & 1.25 \\
\hline 16 & 11 & I have family problems & 1.24 \\
\hline 17.5 & 24 & I don't want to go to classes alone & 1.23 \\
\hline 17.5 & 30 & I feel returning to school won't help & 1.23 \\
\hline
\end{tabular}


TABLE I: RANK ORDERING OF DETERRENTS (CONTINUED)

\begin{tabular}{|c|c|c|c|}
\hline $\begin{array}{l}\text { DPS- } \\
\text { LLR }\end{array}$ & $\begin{array}{l}\text { DPS- } \\
\text { LLS }\end{array}$ & Variables & Mean \\
\hline 20 & 22.5 & $\begin{array}{l}\text { I went to ESL classes somewhere else } \\
\text { and didn't like them }\end{array}$ & 1.22 \\
\hline 20 & 17 & I feel I am too old to learn English & 1.22 \\
\hline 20 & 16 & I don't like doing school work & 1.22 \\
\hline 22 & 20 & $\begin{array}{l}\text { I am worried because classes are held } \\
\text { in a bad neighborhood }\end{array}$ & 1.21 \\
\hline 23 & 30 & $\begin{array}{l}\text { I think "book learning" is not } \\
\text { important }\end{array}$ & 1.20 \\
\hline 24.5 & 20 & I have health problems & 1.19 \\
\hline 24.5 & 25 & $\begin{array}{l}\text { I heard that ESL classes are not very } \\
\text { good }\end{array}$ & 1.19 \\
\hline 26 & 27 & $\begin{array}{l}\text { I think I won't like to be in class } \\
\text { with younger students }\end{array}$ & 1.18 \\
\hline 27.5 & 14 & $\begin{array}{l}\text { I don't think I need to know English } \\
\text { better }\end{array}$ & 1.17 \\
\hline 27.5 & 26 & $\begin{array}{l}\text { I don't want to take classes in a } \\
\text { school building }\end{array}$ & 1.17 \\
\hline 29 & * & $\begin{array}{l}\text { I tried to sign up for free ESL } \\
\text { classes but was told I am not } \\
\text { eligible. }\end{array}$ & 1.14 \\
\hline 30 & 28 & $\begin{array}{l}\text { I feel my family won't like it if I } \\
\text { return to school }\end{array}$ & 1.13 \\
\hline 31.5 & 30 & $\begin{array}{l}\text { I feel that my friends or people I } \\
\text { work with won't like it if I return to } \\
\text { school }\end{array}$ & 1.09 \\
\hline 31.5 & 8 & $\begin{array}{l}\text { I think ESL classes will be like } \\
\text { regular school }\end{array}$ & 1.09 \\
\hline 33 & 18 & $\begin{array}{l}\text { I think that teachers will not be } \\
\text { helpful or understanding }\end{array}$ & 1.07 \\
\hline 34.5 & 20 & $\begin{array}{l}\text { I don't want to answer questions in } \\
\text { class }\end{array}$ & 1.06 \\
\hline 34.5 & 32 & $\begin{array}{l}\text { I don't like other students who go to } \\
\text { classes }\end{array}$ & 1.06 \\
\hline
\end{tabular}


The table also reveals that, similar to Hayes's findings, the most highly ranked deterrents refer to lack of time, costs, low priority of education in relation to work, lack of transportation to school. The items perceived to be the least important include dislike of other students, negative educational experiences, concerns about the negative attitude of family and friends. In other words, ranked the highest are the majority of situational and institutional deterrents, while dispositional deterrents are crowded towards the end. Such distribution of deterrents fits very well with Cross's typology of deterrents (Cross, 1981). Besides being an argument for the general validity of the instrument, this pattern helps show that deterrents are being measured.

Comparison with the Hayes findings at this level is included to show that the survey instrument, although slightly modified, gave very similar results with different populations. With the exception of one item "I don't have time to go to school," - the differences encompass dispositional deterrents only and seem to be logical results of population differences in age and level of education.

The most salient differences seem to be the function of age difference, which entails differences in family 
size and age of the children. The subjects in the present study are considerably older than Hayes's respondents (mean ages 44 and 28 years respectively), which, for Pentecostals, also relates to much larger families and younger dependent children (76\% of Pentecostals and 53\% of Hispanics had at least one dependent child with the average age of five for the youngest child of a Pentecostal and seven for the youngest child of a Hispanic). Thus, work and family commitments for older Pentecostal population take precedence over negative educational experiences and peer pressures and appear to present much more important barriers to participating. As a result, such deterrents as "I think that ESL classes will be like regular school," "I think that teachers will not be helpful or understanding," "I don't want to answer questions in class" were ranked by the Pentecostals in the present study as much less important and were placed at the very bottom of the table. For the same reason the deterrent "It is hard for me to admit that I need help with English" is given much higher rating by the older respondents in the present study.

older age may also explain higher rating by the respondents in the present study of the deterrent "I feel returning to school would not help me" (ranked 9). It seems to reflect their diminished perception of education 
as a means of career development. On the contrary, much younger respondents in Hayes's study, who were just entering the most productive stage of their lives, had more faith in education as a tool to advance in their jobs, which was reflected in their ranking the same deterrent as much less of a barrier to participation (ranked 22.5).

The other group of differences in ranking of the deterrents to participation in ESL programs by the Pentecostals in the present study and by the Hispanics in Hayes's study, stems from the generally higher education level of respondents in this study: Hispanics in Hayes's study were described as low literate, while subjects in the present study had on the average ten and a half years of education. Thus, it was not surprising that this better educated and thus more appreciative of the value of education population rated "I don't think I need to know English better" and "It is more important to get a job than go to school" as less important than the low literate respondents in Hayes's study rated the same deterrents.

Given these differences in the two groups, the similarities in the responses make a strong argument for the validity and reliability of the DPS-LL and its Russian translation (DPS-LLR) as survey instruments. 


\section{FACTOR SOLUTION}

Although the means of the 35 items constituting reasons for nonparticipation are useful for the purpose of description, taken together the number of items portrays a picture too complex to understand easily. For this reason, the responses to the 35 items were factor analyzed to determine whether an underlying structure was apparent.

Initially, this analysis yielded eleven factors that met the Kaiser criterion for retention, possessing eigenvalues greater than 1.0. However, considerations of parsimony led to the examination of factor solutions for between two and eleven factors. Finally, and based on the results of the scree test and subjective judgements of interpretability, a six-factor solution (with the loading criterion set at .40) was selected as the conceptually most meaningful representation of the data, accounting for 50.3\% of the scale variance, with Factors I through VI explaining $21 \%, 7.3 \%, 6.6 \%, 5.8 \%, 5 \%, 4.5 \%$, respectively

The overall mean importance score for the 35 items was a relatively low 1.34 , a finding similar to results of previous research (Darkenwald \& Valentine, 1985; Hayes, 1989; Hayes \& Darkenwald, 1988). 
The results of factor analysis, which addresses the second research question, are presented in Tables II through VII. The tables list DPS-LLR items, item means, item rank according to mean, and factor loadings of each deterrent that define a factor.

Based on the .40 loading criterion, only five items failed to load on any factor:

1) I can't pay for transportation.

2) It is hard for me to admit that I need help with English.

3) I don't like doing schoolwork.

4) I think that teachers will not be friendly or understanding.

5) It's easier for me to learn English if teachers explain rules in my native language. factors :

Four items had loadings of more than .40 on two

1) I feel I am too old to learn English.

2) I don't have any transportation to school.

3) I am afraid I am not smart enough to do the work.

4) I think it will take too long for me to finish school.

The first factor found was called "Self/School

Incongruence." This is the name that Hayes (1989) gave her first factor in the study of Hispanics. The similarity between this and Hayes's Factor I is striking: her factor holds eleven variables including seven in Table II $(1,2,3,6,7,9,12)$. 
English."

TABLE II

FACTOR I : SCHOOL/SELF INCONGRUENCE

\begin{tabular}{||l|l|c|c|c||}
\hline \multicolumn{1}{||}{ VARIABLE } & $\begin{array}{c}\text { Loading } \\
\text { Value }\end{array}$ & $\begin{array}{c}\text { Item } \\
\text { Mean }\end{array}$ & $\begin{array}{c}\text { DPS-LLR } \\
\text { Scale } \\
\text { Rank }\end{array}$ \\
\hline 1 & $\begin{array}{l}\text { I don't want to take } \\
\text { classes in a school } \\
\text { building }\end{array}$ & .78 & 1.17 & 28.5 \\
\hline 2 & $\begin{array}{l}\text { I don't want to answer } \\
\text { questions in class }\end{array}$ & .76 & 1.06 & 35.5 \\
\hline 3 & $\begin{array}{l}\text { I think "book learning" is } \\
\text { not important }\end{array}$ & .68 & 1.20 & 23 \\
\hline 4 & $\begin{array}{l}\text { Starting classes will be } \\
\text { difficult with lots of } \\
\text { questions and forms to } \\
\text { fill out. }\end{array}$ & .67 & 1.25 & 15 \\
\hline 5 & $\begin{array}{l}\text { I don't want to go to } \\
\text { classes alone }\end{array}$ & .66 & 1.18 & 26 \\
\hline 6 & $\begin{array}{l}\text { I think I won't like being } \\
\text { in classes with younger } \\
\text { students }\end{array}$ & .63 & 1.23 & 17.5 \\
\hline 7 & $\begin{array}{l}\text { I feel returning to school } \\
\text { won't help me }\end{array}$ & .63 & 1.23 & 17.5 \\
\hline 8 & $\begin{array}{l}\text { I am afraid I am not smart } \\
\text { enough to do the work }\end{array}$ & .55 & 1.41 & 11 \\
\hline 9 & $\begin{array}{l}\text { I feel I am too old to } \\
\text { learn English }\end{array}$ & .54 & 1.22 & 20 \\
\hline 10 & $\begin{array}{l}\text { I don't have any } \\
\text { transportation to school }\end{array}$ & .43 & 1.42 & 10 \\
\hline 11 & $\begin{array}{l}\text { I went to ESL classes } \\
\text { somewhere else and didn't } \\
\text { like them }\end{array}$ & .43 & 1.22 & 20 \\
\hline 12 & \begin{tabular}{l} 
I have health problems \\
\hline
\end{tabular} & .42 & 1.19 & 25.5 \\
\hline
\end{tabular}

Despite the fact that items loading on Factor I have relatively low means, this factor seems to be one of the 
most conceptually meaningful. The general feeling conveyed strongly by the factor is lack of congruence between self-perception, individual needs, expectations and preferences as compared with different aspects of the educational environment.

The two highest loading items: "I don't want to take classes in a school building" and "I don't want to answer questions in class" indicate a discrepancy between the respondents' self-perception and their role as a student. The same general feeling is supported by items "I am afraid I am not smart enough to do the work," "I have health problems" and "I feel I am too old to learn Items "I think 'book learning' is not important" and "I feel returning to school won't help me" reflect a conflict between perceived individual needs and benefits of education.

The next set of items - "I don't want to go to classes alone" and "I think I won't like being in classes with younger students" - reveals perceived incompatibility with other students in the program. Two items - "Starting classes will be difficult with lots of questions and forms to fill out" and "I don't have transportation to school" - reflect a discrepancy between the subjects' expectations of class organization and perceived reality. These particular variables 
represent an addition of institutional deterrents to an otherwise exclusively dispositional factor and, thus, help Factor I form a coherent mix of institutional and dispositional deterrents.

Finally, the item "I went to ESL classes somewhere else and didn't like them," while introducing a new dimension, is not inconsistent with the foregoing interpretation: it reinforces generally negative feelings prompted by the perceived self/school incongruence. In conclusion, the following observation seems to merit mention. Half of the variables $(2,5,6,7,8,9$, 12) comprising Factor I clearly relate to the respondents' perception of their age-set status (for example, "I think I won't like being in classes with younger students," "I feel I am too old to learn English"). Implicit in such grouping of variables is connotation of "old" age as a deterrent to successful learning. This leads to the conclusion that for this population, "Self/School Incongruence" is to a greater degree associated with age.

Items comprising Factor II are presented in Table III. 
TABLE III

FACTOR II: LOW PRIORITY OF EDUCATION

\begin{tabular}{||l|l|l|l|l||}
\hline \hline \multicolumn{1}{|c|}{ Variables } & $\begin{array}{l}\text { Loading } \\
\text { Value }\end{array}$ & $\begin{array}{l}\text { Item } \\
\text { Mean }\end{array}$ & $\begin{array}{l}\text { DPS- } \\
\text { LLR } \\
\text { Scale } \\
\text { Rank }\end{array}$ \\
\hline 1 & $\begin{array}{l}\text { I don't think I can go to } \\
\text { classes regularly }\end{array}$ & .73 & 1.69 & 4 \\
\hline 2 & $\begin{array}{l}\text { I don't have time to go to } \\
\text { school }\end{array}$ & .70 & 1.58 & 7 \\
\hline 3 & $\begin{array}{l}\text { I think it will take me too } \\
\text { long to finish school }\end{array}$ & .52 & 1.80 & 2 \\
\hline 4 & $\begin{array}{l}\text { The classes are held at } \\
\text { times when I can't go }\end{array}$ & .52 & 1.61 & 6 \\
\hline 5 & $\begin{array}{l}\text { It's more important to get a } \\
\text { job than go to school }\end{array}$ & .50 & 1.40 & 12 \\
\hline 6 & $\begin{array}{l}\text { I am afraid I am not smart } \\
\text { enough to do the work }\end{array}$ & .41 & 1.41 & 11 \\
\hline
\end{tabular}

Except for item 6, the rest of the items in Factor II are found in Hayes's Factor IV, which she labeled "Situational Constraints." However, Hayes's definition of the factor seems to be unjustifiably general. A more specific definition could be "Time Constraints," since the four highest loading variables clearly convey "lack of time" as an obvious label.

However, the fifth and the sixth items indicate a more subtle interpretation. Firstly, both of them refer to a situation in which other activities take precedence over education. Secondly, this factor seems to be closely interrelated with Factor VI "Social Disapproval". For 
these reasons, and based on the researcher's knowledge of the subjects, it was deemed more appropriate to call this factor "Low Priority of Education."

The items comprising this factor exhibit some of the highest item means, with the mean item mean exceeding those of five other factors. This suggests that these deterrents are particularly salient for the described population.

The third Factor, presented in Table IV, was labeled "Negative Attitude Towards Classes".

\section{TABLE IV}

FACTOR III: NEGATIVE ATTITUDE TOWARDS CLASSES

\begin{tabular}{||l|l|l|l|l||}
\hline \hline & \multicolumn{1}{|c|}{ Variables } & $\begin{array}{l}\text { Loading } \\
\text { Value }\end{array}$ & $\begin{array}{l}\text { Item } \\
\text { Mean }\end{array}$ & $\begin{array}{l}\text { DPS- } \\
\text { LLR } \\
\text { Scale } \\
\text { Rank }\end{array}$ \\
\hline 1 & $\begin{array}{l}\text { I don't like the other } \\
\text { students who go to classes }\end{array}$ & .67 & 1.06 & 1.06 \\
\hline 2 & $\begin{array}{l}\text { I tried to start classes but } \\
\text { they were already full }\end{array}$ & .59 & 1.53 & 1.53 \\
\hline 3 & $\begin{array}{l}\text { I think that ESL classes will } \\
\text { be like regular school }\end{array}$ & .56 & 1.09 & 32.5 \\
\hline 4 & $\begin{array}{l}\text { I heard that ESL classes are } \\
\text { not very good }\end{array}$ & .54 & 1.19 & 25.5 \\
\hline 5 & $\begin{array}{l}\text { I am worried because classes } \\
\text { are held in a bad } \\
\text { neighborhood }\end{array}$ & .48 & 1.21 & 22 \\
\hline
\end{tabular}

Negative attitude to school has been consistently shown by numerous studies to be a major reason for 
nonparticipation (see, for example, Beder, 1990; Dao, 1975; Hayes \& Darkenwald, 1988).

The variables subsumed under Factor III in the present study provide for a wider definition of classes, which includes not only their content, but also such aspects as other students attending the classes, location of the building, accessibility of the classes. Each item in Factor III indicates a dislike of one of these aspects: "I don't like the other students who go to classes" reflects a negative attitude to other students; "I tried to start classes but they were already full" reveals negative emotions prompted by the lack of access to classes; "I think that ESL classes will be like regular school" and "I heard that ESL classes are not very good" indicate dislike of classes themselves; and, finally, "I am worried because classes are held in a bad neighborhood" relates apprehension concerning the location of the building.

For the most part, the items comprising Factor III reflect a personal judgment rather than a barrier erected by the institution. For this reason the factor was called "Negative Attitude to Classes" as opposed to "Institutional Barriers."

On the whole, the variables in this factor did not receive high ratings by the respondents, which indicates 
relatively low importance of the factor for the surveyed population.

Items subsumed under Factor IV Low Self-Confidence are listed in Table $\mathrm{V}$.

TABLE V

FACTOR IV: LOW SELF-CONFIDENCE

\begin{tabular}{||l|l|l|l|l||}
\hline & \multicolumn{1}{|c|}{ Variable } & $\begin{array}{l}\text { Loading } \\
\text { Value }\end{array}$ & $\begin{array}{l}\text { Item } \\
\text { Mean }\end{array}$ & $\begin{array}{l}\text { DPS- } \\
\text { LIR } \\
\text { Scale } \\
\text { Rank }\end{array}$ \\
\hline 1 & $\begin{array}{l}\text { I don't know anyone who is } \\
\text { attending the classes }\end{array}$ & .78 & 1.26 & 14 \\
\hline 2 & $\begin{array}{l}\text { I feel I am too old to learn } \\
\text { English }\end{array}$ & .54 & 1.22 & 20 \\
\hline 3 & $\begin{array}{l}\text { I don't know there is any } \\
\text { place to go to take classes }\end{array}$ & .54 & 1.38 & 13 \\
\hline 4 & $\begin{array}{l}\text { I tried to sign up for free } \\
\text { ESL classes but was told that } \\
\text { I am not eligible }\end{array}$ & .50 & 1.14 & 29 \\
\hline 5 & $\begin{array}{l}\text { I think it will take too long } \\
\text { for me to finish school }\end{array}$ & .41 & 1.80 & 2 \\
\hline
\end{tabular}

Variables comprising this factor are mostly dispositional and seem to convey a pattern of lack of confidence: feelings of inadequacy ("I don't know anyone who is attending the classes," "I feel I am too old to learn English," "I tried to sign up for the classes but was told that I am not eligible"), low expectations ("I think it will take too long to finish school") and 
perception of the need for encouragement ("I think it will take too long to finish school").

"Low Self-Confidence" is a dispositional factor, the most difficult to measure. While the items in this factor were assigned moderate means, the factor structure, in conjunction with the expectations from the literature, show that low self-confidence is, in fact, a definite barrier to participation for the subjects of the study.

It is interesting to note that "I am afraid I am not smart enough to do the work" failed to load on this factor at the criterion level, which suggests that "I am afraid I am not smart enough to do the work" is perceived by the respondents as somewhat different from the rest of the items comprising "Low Self-Confidence" factor. This represents a challenge to those who would try to group the deterrents according to what they consider to be logical.

The three items that comprise Factor $\mathrm{V}$ are presented in Table VI. For obvious reasons, this factor has been labeled "Situational Barriers," as defined by Johnstone and Rivera (1965), Cross (1981), Darkenwald and Merriam (1982). It includes three items: "I can't pay for child care," "I have family problems," and "I don't have any transportation to school." 
TABLE VI

FACTOR V: SITUATIONAL BARRIERS

\begin{tabular}{||l|l|l|l|l||}
\hline \hline \multicolumn{1}{|c|}{ Variable } & $\begin{array}{l}\text { Loading } \\
\text { Value }\end{array}$ & $\begin{array}{l}\text { Item } \\
\text { Mean }\end{array}$ & $\begin{array}{l}\text { DPS- } \\
\text { LLR } \\
\text { Scale } \\
\text { Rank }\end{array}$ \\
\hline 1 & I can't pay for child care & .73 & 1.65 & 5 \\
\hline 2 & I have family problems & .66 & 1.24 & 16 \\
\hline 3 & $\begin{array}{l}\text { I don't have any } \\
\text { transportation to school }\end{array}$ & .49 & 1.42 & 10 \\
\hline
\end{tabular}

Interestingly, two of the three items reflect situational difficulties directly related to family.

The items have relatively high means, which suggests that family related situational barriers are an important deterrent for this particular population.

Most of the variables with the lowest means of the scale are found subsumed under Factor VI presented in Table VII.

The highest loading items clearly indicate that support from the immediate environment is perceived as deficient for engagement in education activities.

The third item "I don't think I need to know English better" does not seem to fit the dominant pattern. It might, however, be viewed as a concomitant of the social environment in which education is not perceived as important or helpful. 
TABLE VII

FACTOR VI: SOCIAL DISAPPROVAL

\begin{tabular}{||l|l|l|l|l||}
\hline \multicolumn{1}{|c|}{ Variables } & $\begin{array}{l}\text { Loading } \\
\text { Value }\end{array}$ & $\begin{array}{l}\text { Item } \\
\text { Mean }\end{array}$ & $\begin{array}{l}\text { DPS- } \\
\text { ILR } \\
\text { Scale } \\
\text { Rank }\end{array}$ \\
\hline 1 & $\begin{array}{l}\text { I feel that my friends or } \\
\text { people I work with won't } \\
\text { Iike it if I return to } \\
\text { school }\end{array}$ & .68 & 1.09 & 32.5 \\
\hline 2 & $\begin{array}{l}\text { I feel my family won't like } \\
\text { it if I return to school }\end{array}$ & .58 & 1.13 & 30 \\
\hline 3 & $\begin{array}{l}\text { I don't think I need to know } \\
\text { English better }\end{array}$ & .49 & 1.17 & 28.5 \\
\hline
\end{tabular}

It is important to note that although the items in this factor have the lowest means, "Social Disapproval" is not necessarily the least important deterrent. Due to social desirability bias or what Sudman and Bradburn (1974) called "problems of self-presentation," the items comprising this factor were not likely to be reported at a much stronger level:

If a respondent has a socially undesirable attitude or if he has engaged in socially undesirable behavior, he may face a conflict between a desire to conform to the definition of good behavior, which says one should tell the truth, and the desire to appear to the interviewer to be in a socially desirable category. It is frequently assumed that most respondents resolve this conflict in favor of biasing their answer in the direction of social desirability. (Sudman \& Bradburn, 1974, pp.9-10)

So the dispositional deterrents to socially desirable behavior such as education may well come at the 
end of the list because strong responses to these deterrents do not reflect well on the respondents. Thus, the importance of the factor "Social Disapproval" may be more pronounced than its mean item score leads us to believe.

\section{RELATIONS OF FACTORS TO SOCIO-DEMOGRAPHIC VARIABLES}

The third objective of the research was to determine the relationships between respondent socio-demographic characteristics and factors identified as deterring participation in ESL programs. These relationships are presented in Tables VIII and IX.

Table VIII presents a correlation matrix of the relationships between standardized factor scores and the following socio-demographic variables: age, number of dependent children, age of the youngest child, educational attainment, period of attending ESL classes, years of studying English in the Soviet Union, and period of residence in this country.

Correlations reported in Table VIII were tested for significance. Those that are significant are marked by one asterisk (.05 level of significance) or by two asterisks (an even higher level of significance of .001). 
TABLE VIII

CORRELATIONS BETWEEN FACTOR SCORES AND CONTINUOUS

VARIABLES

\begin{tabular}{|c|c|c|c|c|c|c|}
\hline Factors & $I$ & II & III & IV & $\mathrm{V}$ & VI \\
\hline 1. Age & $\begin{array}{r}.25 \\
*\end{array}$ & -.08 & -.16 & .24 & -.03 & -.19 \\
\hline $\begin{array}{l}\text { 2. Number of } \\
\text { dependent } \\
\text { children }\end{array}$ & $\begin{array}{c}-.31 \\
* *\end{array}$ & .223 & -.06 & -.13 & $\cdot 31$ & .02 \\
\hline $\begin{array}{l}\text { 3. Age of the } \\
\text { youngest child }\end{array}$ & .11 & -.05 & -.17 & .08 & -.07 & -.07 \\
\hline $\begin{array}{l}\text { 4. Educational } \\
\text { attainment }\end{array}$ & -.15 & .13 & .14 & -.13 & .21 & .05 \\
\hline $\begin{array}{l}\text { 5. Period of } \\
\text { attendance of } \\
\text { ESL classes }\end{array}$ & .03 & .16 & .04 & -.16 & .06 & .23 \\
\hline $\begin{array}{l}\text { 6. Years of } \\
\text { studying English } \\
\text { in the USSR } \\
\end{array}$ & -.05 & .08 & -.13 & -.07 & .05 & -.05 \\
\hline $\begin{array}{l}\text { 7. Period of } \\
\text { residence in the } \\
\text { USA }\end{array}$ & -.19 & .07 & .13 & .07 & -.09 & .01 \\
\hline
\end{tabular}

Table IX reports the comparison of means to show how

females and males, and employed and unemployed

respondents differ in their responses to the factors.

Significant differences are marked by asterisks in the same manner as in Table VIII. 
TABLE IX

RELATIONSHIPS BETWEEN FACTOR SCORES AND CATEGORICAL VARIABLES

\begin{tabular}{||l|l|c|c|c|c|c|c||}
\hline \multicolumn{2}{||c|}{ Factors } & I & II & III & IV & V & VI \\
\hline Gender & Female & .14 & -.07 & -.07 & -.05 & .15 & $\begin{array}{c}-.07 \\
.06 \\
\end{array}$ \\
& Male & -.17 & .06 & -.01 & .02 & -.18 & .10 \\
\hline \multirow{2}{*}{ Employment } & Empl. & -.17 & .30 & .16 & .05 & -.28 & .17 \\
& Unemp. & .18 & -.28 & -.16 & -.04 & .29 & -.17 \\
& & & $* *$ & & & $* *$ & \\
\hline
\end{tabular}

As the tables reveal, a number of correlations were found to be statistically significant, their pattern being largely what one would expect.

For example, one would expect School/Self Incongruence (Factor I) to be related to higher age: as the grouping of variables in Factor I clearly indicates, "old" age is perceived by this population as a deterrent to successful learning.

Factor II, Low Priority of Education, was correlated positively with the number of dependent children, also a logical relationship: parents with more children are likely to be more involved with the family, work and community responsibilities which take precedence over education. 
The nature of one's employment has already been established as an important barrier to participation (Anderson \& Darkenwald, 1979). That the participation rate for individuals with high occupational status (professional, managerial employment) is about three times the average for the population as a whole (Kay, 1982) supports the notion that the work setting and job responsibilities do affect adults' inclinations to participate in educational activities: the higher the occupational status of an individual is the more likely he/she is to take part in educational activities. In concert with these findings, Table IX shows that Low Priority of Education (Factor II) was found to be a greater deterrent for the employed respondents in the present study: ESL classes are, in a way, a key to employment in this country; however, once a job (in an almost exclusively unskilled or semiskilled low paying occupation) has been secured, the priority of education decreases considerably.

With respect to Low Self-confidence (Factor IV), the single significant correlate with age makes sense: older adults grow to be less confident in their ability to succeed academically, a finding well illustrated in a number of nonparticipation studies (for example, Johnstone \& Rivera, 1965; Dao, 1975; Carp, Peterson \& 
Roelfs, 1974).

The comparatively high correlation coefficients for Situational Barriers (Factor $V$ ) with number of children and educational attainment also exhibit a consistent, logical pattern. Predictably, the number of dependent children is correlated at a very high significance level with this factor: it seems that more children would require more time on the part of the parents. This makes family commitments a much stronger deterrent to participation in any type of educational activities. As indicated in Table IX, Situational Barriers appear to be significantly greater deterrents to the unemployed respondents. This is not surprising when one considers the cost-related nature of the items that define this factor (for example,"I can't pay for child care," "I don't have any transportation to school"): unemployment leads to financial problems that ultimately present greater barriers to participation to the unemployed (as compared to the employed). This finding reinforces another significant correlation: Situational Barriers with educational attainment.

This seemingly conflicting positive correlation of Situational Barriers with educational attainment (see Table VIII) becomes clear if one takes into account the relatively high level of education of the surveyed 
population (ten and a half years), which, considering the Soviet system of education, makes them mostly blue collar skilled workers who enjoyed relatively high wages in the former Soviet Union. It appears that the more educated the individuals are, the more reluctant they may be to accept lower paying unskilled and semiskilled jobs in this country and, thus, they may be more likely to stay unemployed for longer than their less educated compatriots. Being unemployed, consequently, creates more situational barriers (see the discussion of Situational Barriers-unemployment correlation earlier) •

Responses to Social Disapproval (Factor VI) were found to increase with the length of time spent in ESL programs and decrease with age. The likely explanation for the negative correlation of Social Disapproval and age could be the following. Pentecostalism is a judgmental community, where everyone who wants to be part of it is expected to conform to certain social norms. It appears that younger adults, who are more likely to be in the process of establishing themselves in the community, may find themselves under more pressure to "look good" in the eyes of their older, and, thus, more respected peers. Younger adults might, consequently, be more calculating in producing a socially desirable image. It would be expected then, that in the environment where educational 
activities are not just unsupported, but disapproved, younger adults will be more inclined to perceive this disapproval as a much stronger deterrent than their older counterparts.

Finally, the predictable positive correlation of Social Disapproval and time spent in ESL programs seems to imply that the longer an individual attends an ESL program the more aware she/he becomes of being engaged in a socially undesirable behavior. As a consequence, those who spend more time in English classes come to perceive Social Disapproval of this educational activity as a stronger deterrent.

Only one factor, Negative Attitude to Classes (Factor III), did not correlate significantly with any demographic variable, suggesting that this particular reason for nonparticipation cuts across socio-demographic groupings.

It is clear that, with the exception of one correlation - negative correlation of the number of dependent children with Factor I, School/Self Incongruence (the sole relationship that is hard to interpret), - overall, the socio-demographic variables and factors were found to relate in logical ways, that match expectation from the literature and specific characteristics of the surveyed population. 


\section{CHAPTER V}

\section{DISCUSSION}

\section{INTRODUCTION}

The overall purpose of the present study was to build on earlier (Scanlan \& Darkenwald, 1984; Darkenwald \& Valentine, 1985; Hayes \& Darkenwald, 1988) research which initiated the empirical investigation of deterrents to participation in adult educational activities and extend this line of enquiry to the previously unexamined population: Russian-speaking Pentecostal refugees.

A particular strength of the present study is that it overcame one of the major drawbacks of the previous research (Hayes \& Darkenwald, 1988; Hayes, 1989) that used convenience samples that consisted of participants in adult basic education (Hayes \& Darkenwald, 1988) or in ESL programs (Hayes, 1989). The subjects in those studies were asked to indicate how important each reason was for them BEFORE they started attending those classes. The obvious drawback to the use of such a sample is limited generalizability of the findings. The present research was more successful in reaching the appropriate 
population: although some of the respondents had at some point participated in ESL classes, none of them were at the time of the survey enrolled in ESI programs.

The present study focused on the phenomenon of nonparticipation by addressing the following questions: 1. What individual reasons for nonparticipation are perceived by this population as the most important?

2. Is there an underlying structure to the reasons why eligible members of the target population choose not to attend ESL classes?

3. What socio-demographic and background variables are associated with the reasons why they do not attend the classes?

The information gathered from the three research questions (rank ordering of the deterrents, factor analysis, and exploration of relationships of factors with socio-demographic data) yielded some enlightening statistics about the forces that deter Russian-speaking Pentecostal refugees from participating in ESL programs. Those statistics provided some insight into what is clearly a complex phenomenon. The next three sections of the chapter are devoted to the discussion of the research questions. 


\section{RANK ORDER OF DETERRENTS}

Rank ordering of the 35 items on the DPS-LLR, which was used as the instrument in the study, indicated that the items perceived to be the least important include dislike for school, negative educational experiences, concerns about the negative attitudes of family and friends. The most highly ranked deterrents refer to lack of time, costs, low priority of education in relation to work, and lack of transportation to school.

The one most pressing barrier to participation that stands apart from the rest of the deterrents on the instrument is unavailability of Russian-speaking ESL teachers. It is one of the most significant findings of the study. It will be recalled that the original DPS-LL does not contain the item. The item was added to DPS-LLR after consultations with representatives of the targeted population. Unavailability of Russian-speaking ESL

teachers turned up as the only barrier that was perceived almost twice as important as any other deterrent on the questionnaire. Along with the rank order, the perceived importance of this deterrent is reinforced by its mean score: the rating of 2.51 , which is equivalent to the scale descriptor "Important," stands in contrast to the low ratings of the rest of the items, that ranged between 
"Not Important" and "Slightly Important" (that is, between the scale values of 1 and 2 ).

\section{FACTOR SOLUTION}

With respect to the second research question, exploration of the data revealed six empirically derived, conceptually interpretable factors that represent the basic forces that inhibit Russian-speaking Pentecostal refugees from participating in ESL programs. Reasons why they do not take ESL classes that are offered to them free of charge are multidimensional. They elect not to participate because of the perceived school/self incongruence, low priority of education, dislike for classes, low self-confidence, situational barriers and social disapproval.

The derived deterrent structure was compared to those from prior research of nonparticipation and expectations from the literature. The results of the comparison revealed that, on the one hand, the underlying structure of the deterrents in the present study, although not identical, is nevertheless very similar to the ones derived in the studies of nonparticipation in Adult Basic Education of low-literate adults (Hayes \& Darkenwald, 1988) and nonparticipation in ESL programs 
of Hispanic adults (Hayes, 1989). On the other hand, the deterrent factor structure identified in this study differs substantially, as would be anticipated, from the deterrent structures derived for health professionals (Scanlan \& Darkenwald, 1984) and for the general population (Darkenwald \& Valentine, 1985). The differences between low-literate Americans, Hispanics and Russian-speaking Pentecostal refugees on the one hand and the general population on the other seem to be the function of one key variable - socio-economic status of the respondents. The samples of the research by Scanlan and Darkenwald (1984) and Darkenwald and Valentine (1985) consisted primarily of white, middle-class, highly educated individuals, while respondents in this study, similar to low-literate Americans (Hayes \& Darkenwald, 1988) and low English proficiency Hispanics (Hayes, 1989), belong to the lower social, economic and occupational strata of the society.

That there is a great disparity in the involvement in continuing education of segments of the population situated at different levels of the social hierarchy, is well documented in the literature. For example, Johnstone and Rivera (1965), Miller (1967), Carp, Peterson and Roelfs (1974), Shipp and McKenzie (1981) and, most recently, Beder (1991) point out the differences in 
motivation to participate in adult education among individuals of different socio-economic status. If there are differences in motivation for these groups of population, then it is logical to suggest that there may be differences in the reasons why they do not participate. Following is the discussion of the most salient differences in barriers to participation in various adult education programs between respondents in this study, low literate Americans in the study by Hayes and Darkenwald (1988) and low English proficiency Hispanics in the study by Hayes (1989) (for simplicity these populations will be further referred to as low income) on the one hand and the general population (Darkenwald \& Valentine, 1985) on the other. First, only one factor was found in this study (similar to the findings of Hayes and Darkenwald, 1988 and Hayes, 1989) to correspond to the category of situational barriers proposed by Cross. In the research on the general population this type of barrier was much more complex, being represented by a variety of factors: Time Constraints, Costs and Personal Problems. According to Hayes and Darkenwald (1988), this discrepancy suggests the generally lower level of social involvement and corresponding lack of social commitments among lower income adults. Cost in the present study was not 
identified as a barrier to participation in ESL programs since classes themselves are free.

Second, not a single factor relating to the category of institutional barriers postulated by Cross was identified in this study (similar to Hayes \& Darkenwald, 1989, and Hayes, 1988). Negative Attitude Towards Classes (Factor III) is somewhat related to such institutional types of barriers identified in the research of the general population as Lack of Course Relevance, Benefit and Quality. That institutional barriers failed to form a deterrent to participation in ESL programs was an unexpected finding, considering a number of recent newspaper publications describing enrollment problems, funding reductions, staff cuts, waiting lists and general frustration of eligible individuals trying to get into ESI programs in the Portland area. This testifies to the fact that despite the impression produced by the media, the institutional barriers are not perceived as salient, at least by the Russian-speaking ESL population.

And finally, one of the most revealing differences between low income and general population is a much greater number of dispositional types of barriers experienced by the low income adults. All but one factor - Situational Barriers (Factor V) - in this study had previously been included in the single category labelled 
"dispositional" by Cross (1981) or "psycho-social" by Darkenwald and Merriam (1982). These factors included Self/School Incongruence, Low Priority of Education, Negative Attitude to Classes, Low Self-Confidence and Social Disapproval. In the research with health professionals (Scanlan \& Darkenwald, 1984) and the general population (Darkenwald \& Valentine, 1985), however, in each study dispositional types of barriers were represented by a single factor. Thus, the results of a comparison of barriers to participation in adult education of low income and general population indicate that educational participation of these populations is hindered by essentially different forces: while higher income individuals seem to be "externally" deterred, the low income population is deterred "internally" - the factors that inhibit their participation reside inside themselves and are essentially psychological in nature.

Another important aspect of factor analysis is that by calculating the mean item scores of the six factors, it identified differences in the strength of the deterrent factors. While a variety of deterrent factors may underlie nonparticipation, any individual factor may be strong or weak, thus reflecting the degree of 
importance they were perceived to have had on nonparticipation.

Relative magnitude of the factors according to their mean item scores is graphically represented in Figure 1.

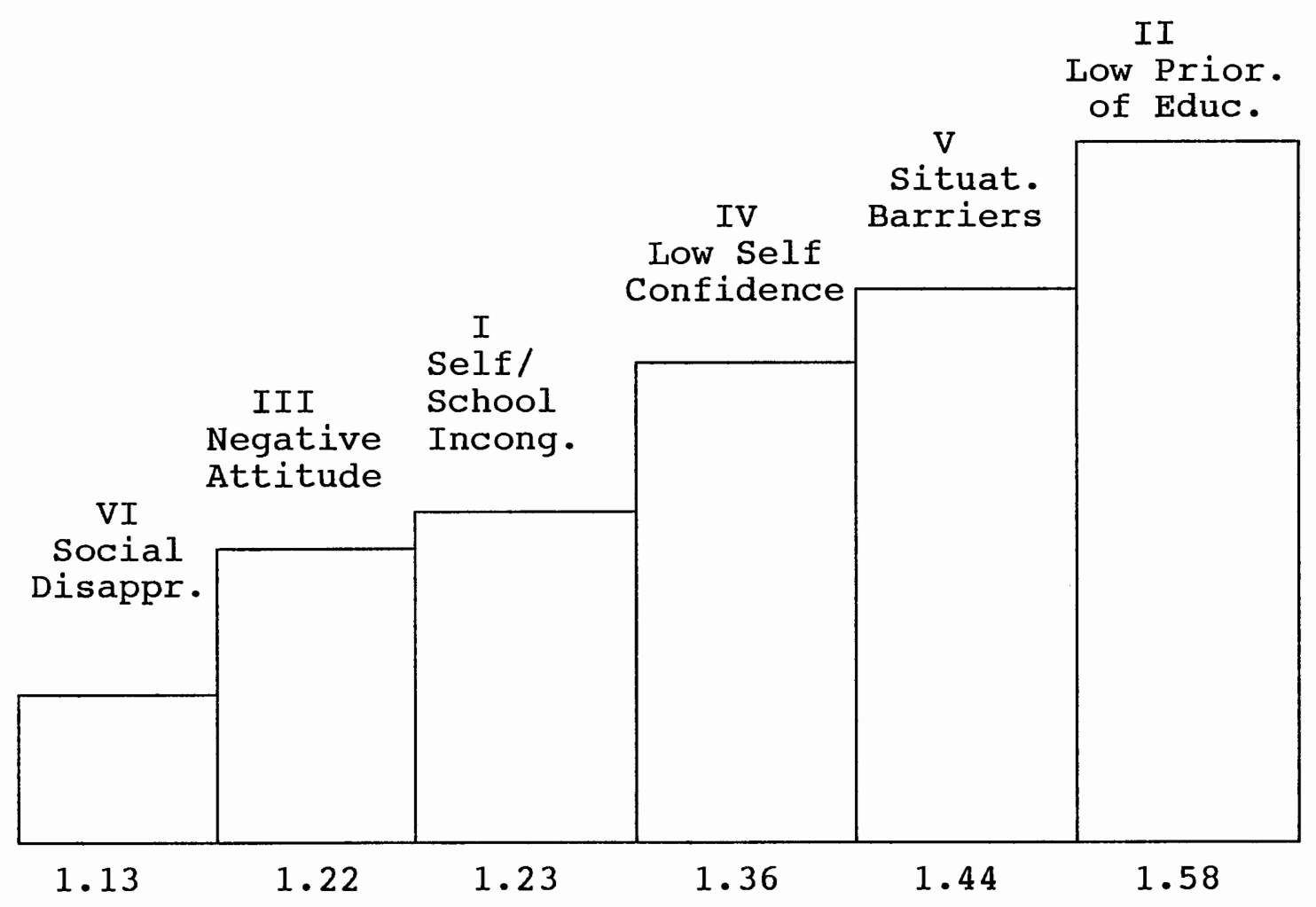

Figure 1. Mean item scores of the factors.

The mean item scores of the factor suggest that Low Priority of Education was perceived as the most important, followed by Situational Barriers and Low Self-Confidence. Self/School Incongruence and Negative Attitude Towards 
Classes were about equal in importance, while Social Disapproval was of secondary importance.

Interestingly, Low Priority of Education, which is perceived as the most important by the Russian-speaking Pentecostal refugees, is unique for this population. The carefully labelled "Low Personal Priority" in the study of low literate adults (Hayes \& Darkenwald, 1988) is somewhat related and similar. However, the unique interrelations of the items in Factor II in the present study clearly focused on particularly education as having low priority. It is tempting to develop this line of thought and infer that the target population is motivated by survival needs rather than by such higher order needs as recognition and self-actualization. However, when trying to interpret the implications of factors, one should be very careful and keep in mind the fact that the present research had as its objective the exploration of factors associated with nonparticipation only. The second major component of participation, motivation, was beyond the scope of the study. Thus, it is virtually impossible to ascertain whether ESL instruction was either actively sought or resisted: if anything, ESL instruction and, along with it, participation in ESL programs, was simply not a priority. 
Predictably, Situational Barriers, perceived as the second important barrier to participation, relate primarily to family and, judging by the results of correlations with socio-demographic data, are associated with having many children. One may infer then that situational barriers derive from role responsibilities associated with family-oriented life cycle and as such operate most substantially during mid-life.

Another interesting finding is the correlation of Situational Barriers with educational attainment and employment. Taken together these correlations provide a very interesting insight into the realities of life for most Pentecostal refugees in this country. One may argue that many find themselves in a "vicious circle": because of their relatively high educational level, Russianspeaking Pentecostal refugees do not want to take low paying jobs but are not offered higher paying ones because of their lack of acceptable level of English proficiency; at the same time, because they are unemployed, they are less likely to participate in ESL programs. As a result, they are neither participating in ESL programs, nor working in the higher paying jobs they may be qualified for. 
Low Self-Confidence (Factor IV) is mostly age related and is the only factor that seems to carry poor self-image.

Self/School Incongruence (Factor I) and Negative Attitude Towards Classes (Factor III) were perceived to be of equal importance.

Self/School Incongruence found in the present study is more clearly defined than the Self/School Incongruence factor reported by Hayes (1989) in the study of nonparticipation of Hispanic adults in ESL programs. In addition to the feeling of lack of congruence between self-perception, individual needs, expectations and preferences as compared with different aspects of the educational environment, it reflects lack of instrumental value of ESL instruction in leading to good jobs or more money

Items subsumed under Negative Attitude Towards Classes provide for a very wide definition of classes, including its content, location, other students attending the classes, the classes' accessibility. These items show that nonparticipants' negative attitudes and perceptions pertain particularly to the existing ESL classes rather than to a more general concept of ESL instruction. Because of this and because of the fact that $64 \%$ of the respondents had at some time participated in ESL programs 
in the Portland area (which means that their opinion was not based on hearsay), this factor can be interpreted as criticism of the existing ESL programs.

Finally, Social Disapproval (Factor VI), which is the least important in terms of item means, represents a very well defined factor, much more clearly separated than in the previous studies. As was discussed in the results section, due to social desirability bias, the items on this factor could have been reported at a lower level of importance than they actually are. Thus, Social Disapproval could be a much more important deterrent than the item means score leads us to believe.

\section{RELATION OF FACTORS TO SOCIO-DEMOGRAPHIC VARIABLES}

With respect to the third research question, the overall pattern of relationships between the factors and socio-demographic variables was conceptually meaningful and consistent with expectations from the literature and the studied population, thereby supporting the validity of the identified factors. Moreover, these observed relationships suggest that as life circumstances and personal characteristics of individuals change, so does their perception of deterrents. In other words, different 
deterrents become prominent at different stages of an individual's life.

That the socio-demographic variables and the factors related in expected ways, along with the consistency of the results with those of previous uses of DPS-LL adds to the validity of DPS-LLR, the research instrument. The fact that the instrument yielded deterrent structure that was logically different from Hayes and Darkenwald's low literate adult population and Hayes's low English proficiency Hispanics, and yet fits the same pattern and the literature, reflects the strength of the instrument and its utility in measuring the deterrents.

One final point merits mention. It concerns the overall low item mean importance scores. Item means ranged between the scale values of 1 (corresponding to the descriptor "Not Important") and 2 ("Slightly Important"), with the scale mean item mean of 1.34 . Low item means were also characteristic of DPS-LL (Hayes \& Darkenwald, 1988) and DPS-LLS (Hayes, 1989) as well as similar instruments designed to identify deterrents to participation. Such a pattern of low item means suggests that an individual's decision not to participate in ESL programs is due to a combination of deterrents rather than just one or two in isolation that, hypothetically, would be easier to deal with. 
Overall, the differences in the findings of the present study and those of earlier research on deterrents to participation do provide evidence of the need to examine the characteristics of Russian-speaking Pentecostal refugees as a distinct group.

From a theoretical perspective, the findings provide a relatively parsimonious framework for understanding deterrents to participation without subscribing to the assumptions underlying simple linear models or simple correlational analysis. The emerged conceptualization of important deterrents specific to Russian-speaking Pentecostal refugees and supported by empirical data has previously been lacking.

For practitioners, the greater understanding of deterrents resulting from this research provides a basis for attempts to serve more Russian-speaking Pentecostal refugees, this still growing segment of ESL population in Oregon. 


\section{CHAPTER VI}

\section{IMPLICATIONS OF THE STUDY}

\section{IMPLICATIONS FOR RESEARCH}

The results of the present study suggest several directions for future research. One of the pressing needs, and one without which this study can only be regarded as suggestive, is for the replication of the factor analytic work. The importance of individual deterrents and the deterrent factors may vary for a wider sample of the target population.

A strength of the present research was that the respondents consisted of members of the target community who had no affiliation with the existing ESL programs and, thus, had not demonstrated a propensity for educational participation. However, choosing such a sample created a problem in regard to social acceptability as a response bias. One of the possible methods to minimize the potential effects of social desirability is a projective technique, whereby the respondents are asked to report perceptions regarding others' behavior. It is assumed that the elicited 
responses would accurately reflect the perceptions of the respondents themselves (Dao, 1975). This technique was not employed in the present research because the results would no longer be comparable to the studies that were replicated.

Since dispositional barriers play such an important role in deterring the target population from participating in ESL programs, more research is needed to understand better their nature. Dispositional barriers are subtle deterrents that are closely tied to selfconcept and, therefore, hard to measure. As deterrents they could have an even greater role than has already been revealed in this research. To allow better measures of dispositional barriers, Martindale and Drake (1989) suggest that instruments designed to access academic self-concept (such as the Academic Self-Concept Scale from the University of Wisconsin at Madison) should be utilized along with a deterrents survey.

Another important issue that needs to be considered in future research of this ethnic minority is the cultural bias inherent in our research tradition. This research tradition is based upon concepts developed by and about the white middle class and as such may be grounded in ethnocentric assumptions (Ponterotto, 1988). Undeniably, one's cultural perspective influences even 
the interpretation of the data. This limitation was partially overcome in this research, since the researcher shares the same ethnic background with the studied population. However, she is not a member of the Pentecostal community. In the future, to enhance the construct validity of factor analytic work it is essential to involve members of the Pentecostal community in the research process.

This research limits its perspective to the study of DETERRENTS to participation. The construct of deterrents to participation as a multifactored influence on adult decisions to participate in education is an important part of a dynamic participation model. The other major component of this model is MOTIVATION. The study of factors that motivate Russian-speaking Pentecostal refugees to engage in learning activities is a very promising area of future investigation.

As was mentioned elsewhere in the paper, the studied sample DOES represent a homogeneous segment of population in respect to all the major characteristics, such as ethnicity, socio-economic status, family status, education and life experiences. However, the information yielded by the consideration of the relationships between deterrent factors and socio-demographic characteristics indicated that the impact of the deterrents on 
participation behavior varies according to both personal characteristics and life circumstances of the individual. This finding suggests that meaningful subgroups can be identified within this seemingly homogeneous population. Identification of such subgroups and creation of a typology of Russian-speaking Pentecostal refugees based on their perception of deterrents to participation in ESL programs seems to be a priority for future research. The results of the suggested research may yield information that could be a valuable resource both for enhancing understanding of participation, and for efforts to improve ESL programs, attract more Russian-speaking Pentecostal refugees into these programs and help this growing segment of population become fully functional, productive members of the society.

\section{IMPLICATIONS FOR PRACTICE}

Viewed from a practical stance, findings of the present research provide useful information for educators and administrators concerned with recruiting, serving and retaining greater numbers of Russian-speaking Pentecostal refugees in ESL programs. By identifying the deterrents that are most negatively affecting participation of this population in ESL programs, the present study provides a 
basis for the development of strategies to address these deterrents.

The number and magnitude of the identified deterrent factors to participation in ESL programs for Russianspeaking Pentecostal refugees suggest that for an ESL program to be successful in addressing these deterrents, the program planners should take a holistic approach to the problem, treating ESL instruction per se as only one need among many. It seems essential that ESI program planning for this population take into account the following broad objectives:

* Reducing family and cost related problems

* Raising self-esteem

* Establishing supportive and responsive learning environment with low levels of risk and free of threat

* Concentrating on helping the participants resume interrupted careers

* Providing a "non-school like" format by stressing an adult oriented environment

* Building more positive attitudes towards ESL classes

* Developing a supportive social environment

* Training of community members as ESL teachers

Reaching these objectives is a formidable task and will require that providers employ an integrated and comprehensive approach to both recruiting and program 
planning. The discussion of recruitment and programming strategies that seem to be most appropriate for the target population follows.

The fact that the present study's respondents had overcome informational barriers indicates that some current efforts of the program providers to convey information about the availability of ESL programs to the target population are successful.

What program planners must recognize is the magnitude of family related problems experienced by this particular population. Careful review of the results of the research demonstrates clearly that family responsibilities of the respondents represent the single most serious cause that lies at the core of the two deterrent factors perceived as the most important by the target population - Low Priority of Education and Situational Barriers. The underlying influence of family responsibilities on the two factors and their interrelations can be described in the following way: to support large families Pentecostal adults have no choice but join the work force as soon as possible; larger families also mean higher expenses, which for low income population translates into financial problems; financial difficulties, ultimately, create such situational barriers as problems arranging child care, lack of 
transportation, etc. Thus, if ESL program planners want to reach the Russian-speaking Pentecostal population, they will need to rethink their responsibilities with respect to learners' families. According to Valentine and Darkenwald (1990), such strategies could include (1) provision of child care in the building where the classes take place; (2) encouraging cooperation between parents whereby they arrange to take care of one another's children during non-conflicting classes; (3) planning and scheduling classes at a site and time compatible with existing child care provision.

Since many situational barriers identified in the present study represent hidden costs (indirect expenses, such as transportation, provision of child care, the "opportunity cost" or loss of income attributed to job leave, etc.), efforts to reduce their impact must be included in any comprehensive strategy to address costrelated barriers to participation. For example, integrating ESL classes within the work setting may be one way to minimize costs.

With the exception of Situational Barriers, the reasons for nonparticipation identified by this study are dispositional in nature and as such relate to subjects' values, attitudes, perceptions or dispositions towards ESL classes. This would suggest that attracting 
nonparticipants to ESL programs will continue to be difficult until either nonparticipants' perceptions are modified or the image of ESL is changed. Both are very challenging tasks and would require that providers employ persuasive communication to enhance the image of the program and directly address the attitudes of the prospective learners.

However, direct communication with this particular community is likely to be impeded by its cultural isolation and by the fact that its members tend to be distrustful of guidance provided by formal organizations (Report, 1993). To overcome these communication barriers it is essential that the program providers establish a strong linkage with the prospective learners. Since religious affiliation plays such a profound role in the life of the Pentecostal community, the Pentecostal church may prove to be a single strong linkage of program providers with the target population.

As an equal partner, the Church will be more likely to engage in collaborative recruiting and program planning. Besides having obvious credibility within the community, the Church can help provide special resources necessary to address many of the aforementioned situational barriers, such as child care, transportation and site provision. 
Collaboration with the Church may also prove valuable in developing a supportive social environment. The importance of Social Disapproval as a barrier indicates that promotion by word-of-mouth may not always be effective: friends and family who do not approve of educational efforts will not be likely to communicate information about ESL programs. That is why recruitment strategies designed to attract Russian-speaking Pentecostal refugees should incorporate personal contact as a component of the promotional effort. Personal contact will be most effective when members of the community serve as recruiters (Irish, 1980). Such individuals can draw on existing networks of personal contacts and, if delegated by the Church, can exert a powerful influence on prospective learners' dispositions towards both themselves and learning.

The Self/School Incongruence factor indicates that (1) in the minds of the surveyed population the design of existing ESL programs in many instances strongly resembles the schooling milieu and that (2) for this population going back to school is a discouraging task. Even though there may be many innovations in ESL programming, the image of teachers and classrooms still dominates the minds of those who dread becoming "students" once again. To reduce this barrier and 
alleviate fears of a competitive academic environment, emphasis in promotional efforts should be put on describing ESL's individualized, adult-oriented program. These strategies can also help build more positive attitudes towards ESL classes.

In terms of methodological approaches, trusting, collaboration, assurance of ample time to master knowledge and skills, creation of positive learning experiences and provision of non-threatening and useful feedback regarding performance may prove beneficial, according to Cross (1981), in reinforcing participants' self-concept and enhancing the learning environment. Other program provisions that can ease the transition for students who lack self-confidence include personalized course requirements, "no-credit-yet" grading (when students have to revise less than satisfactory work before proceeding to the next level) and peer support groups.

As the critical link in bridging potential learners and program provider, the present study identified the need for provision of ESL teachers whose proficiency in the Russian language is high enough to be able to explain rules in Russian. Because of this and because of the aforementioned cultural isolation of the Pentecostal community, it might prove beneficial to staff at least 
lower level ESL classes by teachers with similar ethnic background. This poses certain challenges to teacher training programs, which, in order to accommodate this need, will find it necessary to expand their efforts and try to attract applicants from the Pentecostal community. The efforts of teacher training programs will, ultimately, benefit the whole community: by employing professionally trained indigenous members of the targeted population as ESL teachers, the ESL program planners will make appropriate use of them as role models for enhancing the self-image of prospective participants and ensuring the relevance and worth of the program offerings.

A strength of the research as a guide for practice is the identification of the unique COMBINATION OF DETERRENTS experienced by the Russian-speaking Pentecostal refugees. Because the multiple deterrents appear to have a differential impact upon individuals according to their unique characteristics and life circumstances, it is doubtful that any single strategy will be successful in overcoming their influence. From the perspective of practice, this suggests a need to use a unique COMPLEX OF STRATEGIES that most effectively addresses the multiple deterrent factors. Obviously, the list of strategies discussed in this chapter is by no means exhaustive and should be interpreted as general 
guidelines or suggestions aimed at reducing barriers to participation in ESL programs of Russian-speaking Pentecostal refugees. Clearly, in terms of both number and magnitude of factors involved, addressing deterrents to participation among this population represents a formidable challenge. The choice of particular strategies will, in the long run, depend upon the resources of the program provider. 


\section{REFERENCES}

Anderson, R.E., \& Darkenwald, G.G. (1979). Participation and Persistence in American Adult Education. New York: The College Board, 1969. (ERIC Document Reproduction Service No. ED 029 160).

Beder, H. (1990). Reasons for participation in adult basic education. Adult Education Quarterly, 40, 207-218.

Beder, H. (1991). Adult Literacy: Issues for Policy and Practice. Malabar, Fl: Krieger.

Blane, A. (1977). Protestant sectarians and modernization in the Soviet Union. In D.J.Dunn (Ed.), Religion and Modernization in the Soviet Union (pp. 382-407). Boulder, CO: Westview Press.

Blais, J., Duquette, A., \& Painchaud, G. (1989). Deterrents to women's participation in work-related educational activities. Adult Education Quarterly, 39 (4), 224-234.

Bociurkiw, B.R. (1969). Church-state relations in the U.S.S.R. In M. Hayward, \& W.C.Fletcher (Eds.), Religion and the Soviet State: A Dilemma of Power (pp. 71-104). New York: Frederick A. Praeger.

Booth, A. (1961). A demographic study of non-participation. Adult Education, 11, 223-229.

Bourdeaux, M. (1973). Religious Minorities in the Soviet Union: A report. London: Minority Rights Group.

Bourdeaux, M., \& Reddaway, P. (1969). Church and state and schism: The recent history of the Soviet Baptists. In M. Hayward, \& W.C. Fletcher (Eds.), Religion and the Soviet State: A Dilemma of Power (pp. 105-141). New York: Frederick A. Praeger.

Boshier, R. (1971). Motivational orientations of adult education participants: A factor analytic exploration of Houle's Typology. Adult Education, 21, 3-26.

Boshier, R., \& Collins, J.B. (1985). The Houle Typology after twenty-two years: A large scale empirical test. Adult Education Quarterly, 35, 113-130. 
Burgess, P. (1971) . Reasons for adult participation in group educational activities. Adult Education, 22, $3-29$.

Carp, A., Peterson, R., \& Roelfs, P. (1974). Adult learning interests and experiences. In K.P. Cross, J.R. Valley, \& Associates (Eds.), Planning Nontraditional Programs: An Analysis of the Issues for Postsecondary Education (pp. 11-52). San Francisco: Jossey-Bass.

Cross, K.P. (1981) - Adults as Learners. San Francisco: Jossey-Bass.

Dao, M.N.S. (1975) . The Orientation Toward Nonparticipation in Adult Education. Unpublished doctoral dissertation, University of Chicago.

Darkenwald, G., \& Valentine, T. (1985). Factor structure of deterrents to participation in adult education. Adult Education Quarterly, 35, 177-193.

Darkenwald, G.D., \& Merriam, S.B. (1982) . Adult Education: Foundations of Practice. New York: Harper and Row.

Dowdy, S., \& Wearden, S. (1993) - Statistics for Research. New York: John Wiley \& Sons.

Durasoff, D. (1989). The Soviet state and Russian Protestants. In N.N. Petro (Ed.), Christianity and Russian Culture in Soviet Society (pp. 51-61). Boulder: Westview Press.

Goodman, F.D. (1972). Speaking in Tongues. Chicago: The University of Chicago Press.

Hayes, E. (1988). A typology of low-literate adults based on deterrents to participation in adult education. Adult Education Quarterly, 39, 1-10.

Hayes, E. (1989) - Hispanic adults and ESL programs: Barriers to participation. TESOL Quarterly, 23 (1), 47-63.

Hayes, E., \& Darkenwald, G. (1988). Participation in basic education: Deterrents for low-literate adults. Studies in the Education of Adults, 20, 16-28. 
Hecker, J.F. (1993) - Religion and Communism: A Study of Religion and Atheism in Soviet Russia. Westport: Hyperion Press, Inc.

Hill, K.R. (1989) . The Puzzle of the Soviet Church. Portland, Oregon: Multnomah Press.

Irish, G.H. (1980) . Reaching the least educated adult. In G.G. Darkenwald \& G.A. Larson (Eds), Reaching Hard-to-Reach Adults: New directions for Continuing Education. San Francisco: Jossey-Bass.

Johnstone, J.W., \& Rivera, R.J. (1965) - Volunteers for Learning. Chicago: Aldine.

Juergensensmeyer, M. (1993) . The New Cold War? Religious Nationalism Confronts the Secular State. Berkeley: University of California Press.

Kay, E. R. (1982) - Participation in Adult Education, 1981. Washington, DC: National Center for Education Statistics. (ERIC Document Reproduction Service No. ED 22751).

Kolarz, W. (1962). Religion in the Soviet Union. New York: St. Martin's Press.

Link, S. (1995) - Making the Transition from East to West: Evangelical Christian High School students from the Former Soviet Union. Unpublished master's thesis, Portland State University, Portland, OR.

Locke, S., \& Roberts, A. (1991). Resettlement and acculturation of Soviet Pentecostal refugees in Oregon. The ORTESOL Journal, 12, 33-49.

Martindale, C.J., \& Drake, J.B. (1989). Factor structure of deterrents to participation in off-duty adult education programs. Adult Education Quarterly, 39 (2), 63-75.

Millex, H.L. (1967). Participation of Adults in Education: A Force Field Analysis. Chicago: Center for the study of Liberal Education for Adults.

State of Oregon FFY 1991 Refugee Resettlement Annual Report. (1992, June). Salem, Oregon: Author. 
State of Oregon Adult and Family Services. State of Oregon FFY 1992 Refugee Resettlement Annual Report. (1993, June). Salem, Oregon: Author.

State of Oregon Adult and Family Services. State of Oreqon FFY 1993 Refugee Resettlement Annual Report. (1994, July). Salem, Oregon: Author.

Ponterotto, J.G. (1988). Racial/ethnic minority research in the Journal of Counseling Psychology: A content analysis and methodological critique. Journal of Counseling Psychology, 35, 410-418.

Rubenson, K. (1977) . Participation in Recurrent Education: A Research Review. Paris: Center for Educational Research and Innovation, Organization for Economic Cooperation and Development.

Rubenstein, S. (1994, June 26). Pilgrims. The Sunday Oregonian, p.L4.

Scanlan, C.L. (1986). Deterrents to Participation: An Adult Education Dilemma. Columbus, OH: ERIC Clearinghouse on Adult, Career, and Vocational Education, The National Center for Research in Vocational Education, The Ohio State University. (ERIC Information Series No. 308).

Scanlan, C., \& Darkenwald, G.G. (1984). Identifying deterrents to participation in continuing education. Adult Education Quarterly, 34, 155-166.

Sheffield, S.B. (1964). The orientations of adult continuous learners. In D. Solomon (Ed.), The Continuous Learner (pp. 25-64). Chicago: Center for the Study of Liberal Arts Education for Adults.

Shipp, T., \& McKenzie, L.R. (1981). Adult learners and non-learners: Demographic characteristics as an indicator of psychographic characteristics. Adult Learning, 34 (4), 187-198.

Simon, G. (1974). Church, State and Opposition in the U.S.S.R. Berkeley: University of California Press.

Sudman, S., \& Bradburn, N.M. (1974). Response Effects in Surveys. Chicago: Aldine Publishing Company. 
Valentine, T., \& Darkenwald, G.G. (1990). Deterrents to participation in adult education: Profiles of potential learners. Adult Education Quarterly, 2942 .

Wiggins, P.A. (1994). Soviet Evangelical Students in Adult ESL Classes: A Case Study. Unpublished master's thesis, Portland state University, Portland, OR. 
APPENDIX A

DETERRENTS TO PARTICIPATION SCALE - FORM IL 
Adult Learning Questionnaire - Form LL

Directions: There are many schools and classes for adults who want to read, write, or do math better, or who want to earn a high school diploma or G.E.D. However, some adults do not goto these classes, even if they need help with reading, writing, and math, or want a diploma. Thin  and decide how true each one was for you before you started this adult education class.

Please circle only one number for each reason.

REASONS

How true was each reasor for you before you started this class

Not Somewhat

True True Truoi

1. I couldn't pay for childcare or transportation.

2. I didn't want to take classes in a school building . . . .

4. I didn't want to answer questions in class

5. I didn't have time to go to school . . . . .

6. It was more important to get a job than to go to school.

7. I tried to start classes but they were already full $\therefore$. . .

8 Ididn't want to admit that I needed help with reading . .

9 . The classes were held at times when I couldn't go . . . .

0 id didn't know anyone who was going to the adult education

classes. . . . . . . .

Hil I felt I was too old to learn.

W. I folt my family wouldn't like it if I returned to school

4. I thought starting classes would be difficult, with lots of Xf: questions and forms to fill out

$5 \times 4$ thought it would take too long for me to finish school

Gil don't like doing schoolwork

II I didn't think I needed to read better

8. I thought that adult education would be like regular schoo!

6) I heard that the adult school classes were not very good

of I felt that my friends or people I work with wouldn't like it if I

returned to school

21. I thought I wouldn't like being in classes with younger

xy. students

62 . I thought 'book learning' wasn't important . . . .

3. I was afraid I wasn't smart enough to do the work . .

3it: Ifelt the teachers would not be friendly or understanding 1.

6. I didn't think I could go to classes regularly . . . .

32 I was worried because classes were held in a bad neighborhood..$\quad \therefore$. . .

8. I felt returning to school wouldn't help me . . . . .

9. I didn't like the other students who go to the classes . .

. I went to adult classes somewhere else and didn't like them

Hili I didn't know there was any place to go to take classes

32 . I had family problems

\begin{tabular}{|c|c|}
\hline 1 & 2 \\
\hline 1 & 2 \\
\hline 1 & 2 \\
\hline 1 & 2 \\
\hline 1 & 2 \\
\hline 1 & 2 \\
\hline 1 & 2 \\
\hline 1 & 2 \\
\hline 1 & 2 \\
\hline 1 & 2 \\
\hline 1 & 2 \\
\hline 1 & 2 \\
\hline 1 & 2 \\
\hline 1 & 2 \\
\hline 1 & 2 \\
\hline 1 & 2 \\
\hline 1 & 2 \\
\hline 1 & 2 \\
\hline 1 & 2 \\
\hline 1 & 2 \\
\hline 1 & 2 \\
\hline 1 & 2 \\
\hline 1 & 2 \\
\hline 1 & 2 \\
\hline 1 & 2 \\
\hline 1 & 2 \\
\hline 1 & 2 \\
\hline 1. & 2 \\
\hline 1 & 2 \\
\hline 1 & 2 \\
\hline 1 & 2 \\
\hline 1. & 2 \\
\hline
\end{tabular}


APPENDIX B

DETERRENTS TO PARTICIPATION SCALE - FORM LLR 
My name is Elena Zaitseva. I teach English in a High School. I am also a graduate student at portland state University. My major is Teaching English to Speakers of Other Languages.

One of the major problems that soviet refugees encounter when they arrive to the United States is their inability to speak English. Those who suffer most are adult learners.

The purpose of this questionnaire is to gather information that will help interested organizations develop more effective ESL programs tailored to meet your distinctive needs.

This questionnaire is anonymous and its completion is voluntary.

1. Sex: male/female

2. Age:

3. Native language:

4. Number of years that you have lived in the United States

5. Are you presently employed? Yes/No

6. Have you ever attended ESL classes? Yes/No. If yes, in what year and for how long ?

7. Are you presently attending ESL classes? Yes/No.

8. How many dependent children do you have? How old is the youngest?

9. What schooling did you have in the Soviet Union (write the number of years spent in school, college, etc.) 


\section{REASONS}

1. I can not pay for transportation.

2. I don't want to take classes in a school building.

3. I have health problems.

4. I don't want to answer questions in class.

5. I don't have time to go to school.

6. It is more important to get a job than go to school.

7. I tried to start classes but they were already full.

8. It is hard for me to admit that I need help with English.

9. The classes are held at times when I can't go.

10. I don't know anyone who is attending the classes.

11. I feel I am too old to learn English.

12. I feel my family won't like it if I return to school.

13. I don't have any transportation to school.

14. I think starting classes will be difficult with lots of questions and forms to fill out.

15. I think it will take too long for me to finish school.

16. I don't like doing schoolwork.

17. I don't think I need to know English better.

18. I think that ESL classes will be like regular school.

19. I heard that ESL classes are not very good.

20. I feel that my friends or people I work with won't like it if I return to school. 
21. I think I won't like being in classes with younger students.

22. I think "book learning" isn't important.

23. I am afraid I am not smart enough to do the work.

24. I don't want to go to classes alone.

25. I think the teachers will not be friendly or understanding.

26. I don't think I can go to classes regularly.

27. I an worried because classes are held in a bad neighborhood.

28. I feel returning to school won't help me.

29. I don't like the other students who go to the classes.

30. I went to ESL classes somewhere else and didn't like them.

31. I don't know there is any place to go to take classes.

32. I have family problems.

33. I can not pay for childcare.

34. It is easier for me to learn English if teachers explain rules in my native language.

35. I tried to sign up for free ESL classes but was told that I am not eligible. 
Меня зовут Елена Зайуева. Я преподаю ангхииский язык в школе. Я также учусь в аспирантуре Портландского Государственного Университета, где я изучаю теорию и практику преподавания ангхийкого языка.

Одна ив основных пробхем, С которой стахкиваются советские беженџы по прибытии в США - это неспособность ГОВорить По-анГхийски. Особенно тяжехо это сказывается на хюдях среднего и пожилого возраста.

Уехь моего иссхедования - с помоџью нижеприведенной анкеты собрать информаџию, которая поможет соответствуюшим органам организовать такие курсы ангхииского языка, которые бы похностьк удовхетворяли ваши потребности и учитывахи пробхемы, с хоторыми вы стахкиваетесь.

Эта анкета анонимная и ее заполнение добровохьное.

1. Пох: жен./муж.

2. Bospact

3. РОДНОЙ язЫК:

4. СКохько хет проживаете в США:

5. В настоящее время работаете? Да/Нет

6. Вы изучахи английсхий язык в Советском Союзе? Да/Нет Если да, то скохько лет?

7. Посещахи когда-нибудь курсы ангхияского языха в США? $\mathrm{Za} / \mathrm{HeT}$

Если да, то в каком году и ках дохго ?

8. Посешаете курсы ангкийсого языка в настояшее время? $\mathrm{Za} / \mathrm{HeT}$

9. Скохько у вас несовершеннолетних детей (до 18-ти лет)? - Скохько хет самому мхадшему из них?

10. Кахое образование вы похучихи на родине (укажите общее кохичество хет, проведенное в шкохе, ПТУ, техникуме, BY $\mathrm{Be}$ ) 
обведите хружочхом тохьво одну џыфру $(1,2$ ихи 3$)$ х хаждой из 35 нихеприведенных причин. Степень, в которой к вам относятся нижеприведенные иэречения:

\begin{tabular}{|c|c|c|}
\hline $\begin{array}{l}\text { Ко мHe } \\
\text { He OT- }\end{array}$ & $\begin{array}{c}\text { B каKо - } \\
\text { то сте - }\end{array}$ & $\begin{array}{l}\text { Явス月- } \\
\text { етСя }\end{array}$ \\
\hline $\begin{array}{l}\text { НОСКT- } \\
\text { СЯ }\end{array}$ & 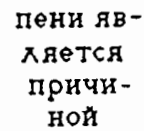 & $\begin{array}{l}\text { при - } \\
\text { чи - } \\
\text { ной }\end{array}$ \\
\hline
\end{tabular}

1. Недостаточно фннансовых средств на транспортные расходы....1 2

2. Не хочу ваниматься в шкохьном зданин............................................ 2

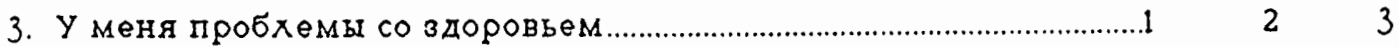

4. Не хочу отвечать на вопросы в к хассе............................................... 2

5. Нет времени ходить на ванятия....................................................... 2

6. Дхя меня гораздо вајжнее найти работу, чем ходить на занятия анг Хйского языха.................................................................

7. Я пытахся/пытаксь ваписаться на курсы анг. азыка, но там уже не быхо/нет свободных мест........................................... 2 2 3

8. Мне тяжело признать, что мне нужна посторонняя помоџь в

9. Занятия проводятся в неудобное дхя меня время.........................

10. Я не знаю никого, хто ходит на курсы ангхийского языка.......... 2

11. Мне кажется, что я уже стар/стара для изучения анг. языка...1 2

12. Мне кажется, что мое возврашение к "шкохьноћ" жизни не очень понравится моей семье

13. У меня пробхемы с транспортировкой х месту занятий (нет машины, не ходят автобусы и т.п. )

14. Мне хажется, что оформхение на хурсы будет схожным придется отвечать на множество вопросов и запохнять много бумаг.

15. Мне хажется, что мне потребуется много врамени, чтобы успешно завершить обучение английскому языку

16. Я не хюбхю выпохнять шкохьные задания 
17. Я думаю, что я достаточно хорошо знаю ангхийский язык........1 2

18. Мне хажется, что хурсы ангхияского языка будут напоминать занятия в советско ̆ шкохе.............................................1 2

19. Я схышах, что курсы ангхийского языка не очень хорошие........ 2 2 3

20. Мне кажется, что моим друзьям и сотрудникам не очень понравится мое решение снова стать ученихом............................. 2

21. Мне не хочется заниматься в одной группе с хюдьми, которые мохоже меня

3

22. Я думаю, что “обучение по книге" не очень важно............................. 2

23. Боюсь, что я не способен выпохнять задания................................... 2

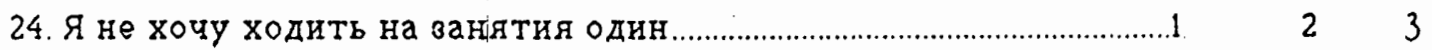

25. Мне кажется, что учитехя на занятиях недружехюбные и

26. Мне кажется, что я не смогу посещать ванятия регулярно.......1 2 2

27. Я обеспокоен тем, что ванятия проводятс६я в опасном районе...1 2

28. Мне хажется, что эти звнятия не помогут мне в овладения ангХй̆ским явыхом

29. Мне не нравятся студенты, хоторые ходят на эти занятия........ 2

30. Я уже посешах подобные хурсы анг. языха, но они мне не понравихись

31. Я не схышах о существовании беспхатных хурсов анг. языка...... 2

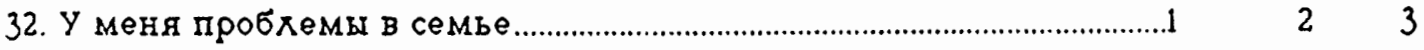

33. У меня недостаточно финансових средств на оплату чеховеху, который будет сидеть с моими детьми во время моего ОтсУТствия

34. Мне хегче выучить ангхийсий язык, есхи учитехя будут объяснять правиха анг. языха на моем родном языке.

35. Я пытахся записаться на беспхатные курсы анг. языка, но мне скавахи, что я не имею права записываться на зти хурсы....1 